\title{
Permanent Sovereignty over Natural Resources and Contract Stability in Transnational Petroleum Investment Contracts
}

\author{
Chukwubuikem J.S. Azoro* Chinedu A. Onah \\ Faculty of Law, Nnamdi Azikiwe University, Awka, Anambra State, Nigeria
}

\begin{abstract}
This paper makes a critical analysis of the principle of permanent sovereignty over natural resources and contract stability as applicable to transnational petroleum investment contracts. It considers the extent to which these concepts affect foreign direct investment in the petroleum industry. This work further demystifies the theory of contract stability as a panacea to the tense environment contrived by the principle of permanent sovereignty over natural resources. The doctrine of pacta sunt servanda as applicable to stabilization clauses is considered towards explicating how it procures stability in oil investment contracts. In this wise, other like devices like renegotiation, clausula rebus sic stantibus, etc are not left out, particularly as they introduce some element of flexibility and attenuate the hardships that might arise due to strict insistence on the application of principle of pacta sunt servanda to the dynamics of the petroleum industry. This work adopts the synthesis and analysis as well as the comparative methodology in reviewing the relevant materials consulted in the course of this work. It argues that parties to transnational petroleum contracts should pursue stability in such agreements through the employment of such devices that ensure flexibility within the context of a dynamic petroleum industry.
\end{abstract}

Keywords: Permanent Sovereignty, Contract Stability, Petroleum Investment Contract, Stabilization Clauses

DOI: $10.7176 / \mathrm{JLPG} / 111-09$

Publication date:July $31^{\text {st }} 2021$

\section{Introduction}

It is beyond dispute that the 'black-gold' (i.e. petroleum) is the main stay of most countries where it abounds in commercial quantities and in Nigeria, accounts for more than 80 percent of government revenues. Thus, it can be reasonably expected that government, through legislations and policy implementations will aim at boosting her income from that sector of the economy, particularly in view of her sovereign rights over her mineral resources. See section 44(3) of the 1999 Constitution of the Federal Republic of Nigeria (as amended); section 1 of the Petroleum Act; and section 1 of the Minerals and Mining Act. Indeed, this trend is a necessary precipitate of the evolutionist principle of resource nationalism as provided in articles 1 and 2 of the United Nations Declaration on Permanent Sovereignty over Natural Resources adopted by UNGA Resolution 1803 (XVII) of $14^{\text {th }}$ December 1962 , and particularly sees developing countries take all steps necessary to ensure that they exercise permanent sovereignty over their natural resources and maximize the benefits accruing from the exploitation of such natural resources (Mato 2012).

However, the government is definitely not the only stakeholder in the petroleum industry. Indeed, international oil companies (IOCs) occupy a strategic position in the industry, in view of the enormity of their investments and operations in the industry. In this regard, transnational mining agreements became the most viable option, particularly as regards the fact that petroleum exploitation involves relatively high capital and expertise requirements, usually beyond the affordability of developing countries (Mato 2012). Indeed, such contractual relationship with IOCs are nigh inevitable.

Considering the extent of the effect governmental policies and legislations may have on the operations and investments of IOCs, it is not uncommon for the latter to be seen expressing fears over risks associated with transnational investments, particularly the risk of the host nation 'expropriating' their investments especially in countries prone to unstable political and economic environments. Faced with transnational investment transactions, IOCs will usually be seen demanding guarantees for the observance of the traditional doctrine of pacta sunt servanda as part of the conditions for their investments. This legal axiom literally means that 'agreements must be kept'. See the cases of Alade v ALIC (Nig) Ltd \& Anor (2010)12 SC (pt. II) 59 at 95; Ekiadolor v Osayande (2010)6 NWLR (pt. 1191) 423. In Sapphire v National Iranian Oil Company (1967)35 ILR 136 at 181, it was held thus: "It is a fundamental principle of law, which is constantly being proclaimed by international courts, that contractual undertakings must be respected. The rule pacta sunt servanda is the basis of every contractual relationship." The overall aim of such demands for guarantee by the IOCs is to ensure contractual stability by binding the host country to refrain from taking such unilateral action that would deprive IOCs from maximum enjoyment of their benefits under such contractual arrangements.

\section{The Concept of Permanent Sovereignty over Natural Resources}

The end of the Second World War saw the dissolution of many colonial empires. Previously subjugated nations thus became independent and sovereign States (Akinsanya 1978). Many of these nations were well endowed in 
natural resources. As a facet of sovereignty and self-determination, these resource-rich nations demanded the right to exploit their natural resources for the purposes of economic development and to better their prospects of economic growth (Miranda 2012). This goal was based on the perceived need to assert themselves on issues such as the control of their natural resources which were largely in the hands of foreign companies (Asante 1979). It was felt that, this state of affairs made nonsense of their newly acquired sovereignty and undermined their desire to develop and exploit their natural resources (Asante 1979). Within the parameters of this goal was the need to reconsider the agreements formalized prior to their independence, a plethora of which were perceived as 'inequitable and onerous (Wart et al. 1988).' This was certainly the case in Aminoil v Kuwait (1982)21 ILM 976 where the concession was granted to Aminoil before Kuwait had obtained her independence from Great Britain.

The need of developing countries to assert authority over natural resources led to the birth of the international law principle of permanent sovereignty over natural resources (Barrera-Hernándes 2006). The principle of permanent sovereignty over natural resources essentially dictates that resource rich nations should have control over their natural resources. However, that control is contingent upon the State utilizing the resources for national development. In addition, in exercising the rights attached to this principle the State must act within the parameters of international law.

\subsection{Evolution of the Principle of Permanent Sovereignty over Natural Resources}

The principle of permanent sovereignty over natural resources evolved through various United Nations General Assembly (UNGA) Resolutions, such as UNGA Resolution 523 (VI) on Integrated Economic Development and Commercial Agreements made on $12^{\text {th }}$ January 1952. However, arguably the 'landmark resolution' was UNGA Resolution 1803 (XVII) (Hossain \& Chowdhury 1984; Duriugbo 2006). The evolution of the principle eventually culminated in the Charter of Economic Rights and Duties of States (CERDS) which as the name suggests highlights the rights and duties of States. The evolution was in four phases (Duriugbo 2006).

During the first phase, which occurred between 1952 and 1962, various resolutions were passed relating to the principle of permanent sovereignty over natural resources. The focus was on the right of mineral rich countries to utilize their natural resources as part of their sovereignty which in turn was a facet of selfdetermination (Duriugbo 2006). The first of these was UNGA Resolution 523 (VI) of $12^{\text {th }}$ January 1952 which recognized the right of under-developed countries 'to determine freely the use of their natural resources' with the added proviso that they do this in order to advance the economic development of their nations. The sentiments expressed herein, were echoed in the subsequent UNGA Resolution 626 (VII) of $21^{\text {st }}$ December 1952 (Hyde 1956), which is seen as the genesis of the doctrine of permanent sovereignty over natural resources (Miranda 2012; Duriugbo 2006; Yackee 2009). Similar sentiments were re-echoed in UNGA Resolution 837 (IX) of $14^{\text {th }}$ December 1954. Under the UNGA Resolution 1314 (XIII) of $12^{\text {th }}$ December 1958, it was recognized that the right to self-determination as affirmed by the 1966 International Covenant on Civil and Political Rights as well as the 1966 International Covenant on Economic, Social and Cultural Rights included 'permanent sovereignty over wealth and natural resources'. Consequently, the same UNGA Resolution 1314 (XIII) of $12^{\text {th }}$ December 1958 established a Commission on Permanent Sovereignty over Natural Resources comprised of both developed and developing countries which was charged with conducting a 'full survey of the status of the permanent sovereignty of people and nations over their natural wealth.' The Commission was to pay particular regard to 'the rights and duties of States under international law and to the importance of encouraging international cooperation in the economic development of under-developed countries.' Indeed, the UNGA Resolution 1515 (XV) of $15^{\text {th }}$ December 1960 reemphasized the fact that whilst permanent sovereignty over natural resources had rights attached to it, these also comes with duties. Surveys conducted by the Commission culminated in the landmark UNGA Resolution 1803 (XVII) of $14^{\text {th }}$ December 1962 (de Sá Ribeiro 2009; Weiss \& Daws 2007). The key provisions of this Resolution are as follows: (a) the right of people's and nations to permanent sovereignty over their wealth and resources must be exercised in the interest of their national development and the well-being of the people of the State concerned; (b) the exploitation, development and disposition of such resources, as well as import of foreign capital required for these purposes should be in conformity with the rules and conditions which the peoples and nations freely consider to be necessary or desirable with regard to the authorization, restriction or prohibition of such activities; (c) in cases where authorization is granted, the capital imported and the earnings on that capital shall be governed by the terms thereof, by the national legislation in force, and by international law; the profits derived must be shared in the proportions freely agreed upon in each case between the investors and the recipient State, due care being taken to ensure that there is no impairment, for any reason, of that State's sovereignty over its natural wealth and resources; (d) nationalization, expropriation, or requisitioning shall be based on grounds or reasons of public utility, security or the national interests, both domestic and foreign. In such cases, the owner shall be paid appropriate compensation in accordance with the rules in force in the State taking such measures in the exercise of its sovereignty and in accordance with international law. In any case where the question of compensation gives rise to a controversy, the national jurisdiction of the State taking such measures shall be exhausted. However, upon agreement by the sovereign State and other parties concerned, 
settlement of the dispute should be made through arbitration or international adjudication; (e) the free and beneficial exercise of the sovereignty of peoples and nations over their natural resources must be furthered by the mutual respect of State based on their sovereign equality; (f) international co-operation for the economic development of developing countries, whether in the form of public or private capital investments, exchange of goods and services, technical assistance, or exchange of scientific information, shall be such as to further their independent national development and shall be based upon respect for their natural wealth and resources; ( $g$ ) violation of the rights of peoples and nations to sovereignty over their natural wealth and resources is contrary to the spirit and principles of the Charter of the United Nations and hinders the development of international cooperation and the maintenance of peace; (h) foreign investment agreements freely entered into by or between sovereign States must be observed in good faith. States and international organizations shall strictly and conscientiously respect the sovereignty of peoples and nations over their natural wealth and resources in accordance with the Charter and the principles set forth in the present resolution.

The second phase occurred between 1962 and 1973. This period has generally been described as one characterized by nationalism and States exerting greater control over the exploitation over the exploitation of their natural resources (Warden-Fernandez 2000). It comes as no surprise therefore that this period also consisted of a number of resolutions adopting, reaffirming and reiterating the UNGA Resolution 1803 (XVII) of 14 ${ }^{\text {th }}$ December 1962 (Hossain \& Chowdhury 1984). This included the UNGA Resolution 2158 (XXI) of 25 th November 1966, Resolution 2386 (XXIII) of $19^{\text {th }}$ December 1968, Resolution 2692 (XXV) of $11^{\text {th }}$ December 1970, the United Nations Conference on Trade and Development (UNCTAD) Resolution 88 (XII) of 19 ${ }^{\text {th }}$ October 1972, and UNGA Resolution 3171 (XXVIII) of December 1973. In addition, a Working Group on the Charter of Economic Rights and Duties of States was established by the UNGA Resolution 45 (III) of $18^{\text {th }}$ May 1972 and enlarged by the UNGA Resolution 3037 (XXVII) of $19^{\text {th }}$ December 1972 and UNGA Resolution 3082 (XXVIII) of $6^{\text {th }}$ December 1973.

The third phase occurred during the Sixth Special Session of the UNGA which took place on the $1^{\text {st }}$ of May 1974. This Session eventually led to the adoption of the Declaration on the Establishment of a New International Economic Order (NIEO) vide UNGA Resolution 3201 (S-VI) of $1^{\text {st }}$ May 1974 and the Charter of Economic Rights and Duties of States vide UNGA Resolution 3281 (XXIX) of 12 $2^{\text {th }}$ December 1974 (Schrijver 1997). There are many rights emanating from these international instruments. For example, paragraph 4 of the Declaration on the Establishment of a New International Economic Order restates the need for each State to exploit its mineral resources for its development and further provides that in order to safeguard these natural resources, each State is entitled to exercise effective control over them and their exploitation with means suitable to its own situation including the right to nationalization and the transfer of ownership to its nationals, this right being an expression of the full sovereignty of the State. Similarly, article 2(2)(c) of the Charter of Economic Rights and Duties of States quite explicitly postulates that States have the right to 'nationalize, expropriate or transfer ownership of foreign property.' The condition attached is that the State pays 'appropriate compensation' which is to be settled under the auspices of domestic law and domestic tribunals, unless otherwise agreed. Article 2(1) of the same Charter provides that the State can freely dispose of its natural resources. It is as a result of this right that States possess the authority to enter into agreements with multinational corporations. It is imperative however, that these agreements are freely entered into. See the decision in Texaco Overseas Oil Petroleum Co. \& Anor $v$ The Government of the Libyan Arab Republic (1978)17 ILM 1 at 66 - 67. Whilst a State can enter into an agreement, a question that has been intensely debated is whether a State can unilaterally abrogate these agreements (Paasirvirta 1989). Under the doctrine of permanent sovereignty over natural resources and as reemphasized in article 2(2)(a) of the Charter of Economic Rights and Duties of States, the State also has the right to regulate and supervise foreign investment and further has the right to nationalize foreign owned property (Schrijver 1997). However, with this right also comes the duty to observe the tenets of international law vis-à-vis the taking of foreign owned property. This includes the duty to compensate foreign owned corporations. Furthermore, there is duty to utilize the natural resources in a way that advances economic development (Schrijver 1997).

The fourth phase is the aftermath of the adoption of the Charter. The evolution and acceptance of this doctrine is determined by examining treaties that have been concluded since 1974. It has been noted that myriad treaties do reflect the rights and duties espoused in the Charter. However, given the adoption of bilateral investment treaties, which advocate full rather than appropriate compensation, the universal acceptance of the Charter may be questioned (Hossain \& Chowdhury 1984; Schrijver 1997).

\subsection{Legal Status of the Principle of Permanent Sovereignty over Natural Resources}

Because the Charter stems from a General Assembly resolution, there are questions as to whether the rights and duties contained therein are binding. On the one hand, it is argued that General Assembly resolutions are not binding (Crawford 2006). It is recognized that the General Assembly does possess 'quasi-legislative' functions (Sands \& Klein 2009). However, it is difficult to argue that the General Assembly is a legislative organ (Sands \& 
Klein 2009). This is firstly owing to the fact that there is an objection to two-thirds majority binding the minority. Secondly, to bind States under General Assembly resolutions may circumvent the traditional treaty making process which, under some national constitutions, requires ratification in order for the State to be bound (Sands \& Klein 2009).

On the other hand, to completely disregard the principles espoused in these General Assembly resolutions would be erroneous. Because of the general procedures that lead to the eventual vote and adoption of a resolution, it could be argued that they constitute evidence of customary international law (Sands \& Klein 2009). A customary rule "comes into existence only where there are acts of State in conformity with it, coupled with the belief that those acts are required by international law' (Bleicher 1969). General Assembly resolutions become customary norms on the basis that the General Assembly is itself a vehicle through which the States form and express the practice of international law are manifested (Sornarajah 2010). The resolution is drafted in such a way that it can win the support of the majority of the Assembly. Typically, more than a bare majority must be ensured before a vote will be called (Bleicher 1969). The resolution will often represent a harmonization of the conflicting views that might have been expressed, prior to the vote being called (Bleicher 1969). Therefore, by the time it is being adopted, it is an expression of the general consensus, which in turn can be construed as the formulation of a customary norm (Bleicher 1969).

Arguably, the General Assembly resolutions pertaining to permanent sovereignty over natural resources do form a part of customary law. This view has been supported by various arbitral tribunals. For example, in the case of Libyan American Oil Company (LIAMCO) v Libya (1977)62 ILR 141, the arbitrator held that, 'the said Resolutions, if not a unanimous source of law, are evidence of the recent dominant trend of international opinion concerning the sovereign right of States over natural resources'. This clearly shows that even arbitral tribunals recognize the general resolutions on permanent sovereignty over natural resources as evidence of customary law. This position was also reflected in Texaco Overseas Oil Petroleum Co. \& Anor v The Government of the Libyan Arab Republic (supra). Here the arbitral tribunal took the view that UNGA Resolution 1803 (XVII) of 14 December 1962 reflected the tenets of customary international law. The arbitral tribunal arrived at this conclusion on the basis that the said resolution referred to international law when it spoke of nationalization, and had received the universal assent of both developed and developing countries (Schwebel 1963). The arbitral tribunal further opined that UNGA Resolution 1803 (XVII) ought to be contrasted with the Charter of the Economic Rights and Duties of States which in the arbitrators view 'must be analyzed as a political rather than as a legal declaration concerned with the ideological strategy of development and, as such, supported only by non-industrialized States' (Schwebel 1963; Lowenfeld 2003; Hossain 1980).

Furthermore, it could be argued that the resolutions pertaining to permanent sovereignty over natural resources are a reflection of rights and duties that already existed under international law (Gess 1964; Baxter 1980). For example, it was already generally recognized that the State had the right to nationalize (Schrijver 1997). Once the State nationalized they also had an obligation to pay compensation (Schrijver 1997). This is therefore another reason why it could be argued that the resolutions pertaining to permanent sovereignty over natural resources are generally binding.

In addition, the principle of permanent sovereignty over natural resources has been accepted by the International Court of Justice. This position was reflected in the decision in East Timor (Portugal v Australia) (1995) ICJ Rep 90. In more recent times the principle of permanent sovereignty over natural resources has gained more recognition. In the Case concerning Armed Activities on the Territory of the Congo (Democratic Republic of the Congo v Uganda) (2005) ICJ Rep 168, the International Court of Justice recognized permanent sovereignty over natural resources as a principle of customary international law but decided that the principle does not apply to situations of looting, pillage and exploitation of natural resources by members of the army of a State militarily intervening in another State. In the same case, Judge Koroma however contended that the acknowledgement of the principle as a customary norm implies that the rights and duties emanating from it remain in effect at all times, including during armed conflict and occupation. Given the fact that decisions of the International Court of Justice are a source of international law, it could thus be asserted that the principle of permanent sovereignty over natural resources as well as the rights and duties emanating therefrom is firmly accepted under international law, and that it is under this principle that States are able to enter into agreements with investors (Dufrense 2004; Maniruzzaman 2001). It is also arguable that under this principle, the word 'permanent' suggests that the State has the right to exit these agreements at any given time, regardless of an agreement not to do so (de Arechaga 1978). This is however not the case. Indeed, such a state of affairs portends serious dangers for transnational oil investments and highlights the need for stability in such investment agreements.

\section{Contract Stability in Transnational Petroleum Investment Contracts}

Of the plethora of concerns that haunt investors engaged in petroleum development, 'political risks' tend to appear at the forefront. A number of definitions, albeit similar, have been offered to define the concept of 
'political risk'. Comeaux and Kinsella defined it as “... the risk that the laws of a country will unexpectedly change to the investor's detriment after the investor has invested capital in the country, thereby reducing the value of the individual's investment" (Comeaux \& Kinsella 1994). Drawing a clear distinction from commercial risks or uncertainties that could arise as a result of a change in economic conditions, Wells defines political risks as "...those risks that are principally the result of forces external to the industry and which involve some sort of government action or, occasionally, inaction" (Moran 1998). Irwin illustrates that "[T]hese risks can take different forms including disruption of equity participation (by dilution or expropriation), forced renegotiation of contracts, forced contracting procedures, avoidance of agreed commitments, revision of regulation, or any political/cultural change which may impact priorities and disrupt your business plans" (Moran 1998). Indeed, investors are much wary of these risks when in particular the host state's level of political governance is generally rated as poor and unstable (Humphreys et al. 2007). Understandably, investors anticipate such risks since they remain unavoidable and inherent to the nature of long term projects such as petroleum development (Kolo 1994). To avoid such augury from becoming a reality, ostensibly, investors demand guarantees from the government. Such contractual guarantees are believed to be a vaccine for such risks (Johnson 1994). Such a measure is principally aimed at creating, inter alia, a stable fiscal regime that would otherwise be vulnerable to the unilateral whims and caprices of the government, an unflattering situation no investor wishes to be at. It is not therefore a coincidence that several contractual guarantees feature in a number of petroleum investment agreements (Maniruzzamann 2007). With oil having a volatile world price and the nature of investment in the sector destined to be for a relatively longer period, one cannot overemphasize the significances of maintaining the stability of contractual undertakings. It should however be noted that even such guarantees could be crumbled into dust in just a twinkling of an eye.

It follows therefore that stability of contractual agreements is the major means of investment protection at the disposal of IOCs. This is usually achieved by inserting certain clauses in contractual agreements with their host countries to ensure that future changes in policy or legislation of the host country does not affect the existing agreement (Mato 2012).

Such clamour for contractual guarantee is usually as a result of conflicts in interest between the government of the host country and the IOC. A major source of such conflict between host governments of developing countries and IOCs derives from the preoccupation of the IOCs with stability and predictability in contractual relations on the one hand, and the persistent demands of host governments for a more flexible contractual regime on the other (Mato 2012). This is because the underlying objectives of the two parties are significantly divergent. While host governments aim at promoting economic growth and development through such foreign investment, the multinationals are merely concerned with maximization of profit at the least risk (Gao 1994). The insistence of IOCs on the traditional doctrine of pacta sunt servanda is premised on the stability and predictability of contractual relations which the doctrine affords. Such clauses (otherwise referred to as stabilization clauses) inhibit governments from unilaterally interfering with their agreement with IOCs and give the IOCs the leeway to operate. On the other hand, host countries would want a contractual regime which is flexible in view of the ever changing circumstances of the petroleum industry.

The doctrine of pacta sunt servanda, though indicative of the fact that no party is entitled to unilaterally modify a contract, is not in any way suggestive of the fact that the contract is immutable, after all, parties cannot contract to commit a crime or to perpetuate an illegal act, such as fraud, duress and misrepresentation. In such cases, any attempt to invoke the doctrine of pacta sunt servanda so as to preserve the contract will fail. See the cases of ACB Ltd v Alao (1994)7 NWLR (pt. 358) 614; JFS Investment Ltd v Brawal Line Ltd \& 2 Ors (2010)12 SC (pt. 1) 110; Chief AN Onyuike III v GF Okeke (Unreported) Supreme Court of Nigeria Judgment in Suit No: SC/430/74 delivered on $5^{\text {th }}$ May, 1976. Thus, it has been argued that a rigid application of the principle of pacta sunt servanda to stability clauses in transnational petroleum contracts involving IOCs derogates from the sovereign rights of the host country to her natural resources such that the applicability of the doctrine need be relaxed. Converse arguments however maintain to the effect that since the host countries willingly conclude such contracts in exercise of their sovereign powers, the applicability of the doctrine cannot amount to a derogation from their sovereignty but is rather an affirmation of same. Though neither view has succeeded in eroding the other, it may safely be asserted that there is currently a gradual but remarkable modification of the traditional concept through the mechanism of incorporating revision clauses (otherwise called renegotiation clauses) into such transnational petroleum agreements (Dolzer \& Schreuer 2012).

Apart from the stabilization and renegotiation clauses, political risk insurance, hardship clauses and dispute settlement clauses are also veritable in procuring a relatively stable and viable environment for petroleum investment contracts to thrive (Subedi 2012). These contract stabilization devices will be considered in some detail.

\subsection{Background to the Concept of Stabilization Clauses}

Usually, when a host State is entering into an investment contract with an investor, the former is prepared to 
accept whatever terms are dictated by the latter (Ng'ambi 2014). This is largely influenced by the fact that the host State often needs the investor's capital to exploit its natural resources. Thus if it does not put itself in an adequately competitive position, it runs the risk of the investor seeking alternative jurisdictions in which to utilize their capital (Ng'ambi 2014). The investor is clearly in a stronger position during the negotiation stages of the contract because they are relying on a bargaining power derived from the States need for foreign capital (Woodhouse 2006). Once the agreement is signed, and operations commence, it is the State that becomes the stronger party and the investor becomes the weaker party. This is because the State has various prerogatives at its disposal. It could therefore utilize these to override previous contractual undertakings which in turn may jeopardize the investor's prospects of making a profit in the host State (Sornarajah 2010).

Thus, of concern to an investor when entering into an investment agreement is whether the host government will abide by the terms of that agreement for the entirety of its term. It is clear that an ordinary contract, without stabilization clauses, will generally be governed by the municipal law of the host State (Ng'ambi 2010). From the investors' perspective, this means that the law can be altered at any time by the legislature of the host State and these laws can be amended in a way disadvantageous the investor. Such a state of affairs puts the investor in a somewhat precarious position, especially in instances where a nationalistic mood sweeps the host State (Maniruzzaman 2009). The advanced stages of the resource nationalism cycle typically occur in times when the investor is making windfall profits from the investment (Vivoda 2009). In times like these the host State will reconsider the agreements and will seek to maximize the benefits attained from their natural resources (Waelde \& Ndi 1996). They may consider altering tax legislation, so that they may gain a proportion of the windfall profits, or to achieve the effect of significantly reducing the investor's profits or simply make it more onerous or expensive to run operations in a given jurisdiction (Nwaokoro 2013). A good example is the Nigeria Liquified Natural Gas Project. Despite the numerous guarantees granted the partner investors in the project by the Nigerian government which guarantees are even statutorily encapsulated in the Nigeria LNG (Fiscal Incentives, Guarantees and Assurances) Act, the country has gone ahead to enact some legislations including tax laws adversely impacting cum limiting those guarantees. An example is the Niger Delta Development Commission (Establishment, etc) Act, the constitutionality of which was upheld by the Court of Appeal in the case of NDDC $v$ NLNG Ltd (2010) LPELR-CA/PH/520/2007. The host country may even terminate the contract prematurely and nationalize assets belonging to the investor by utilizing the legislative process (Waelde \& Ndi 2006; AlFaruque 2006).

As a buffer against this, foreign investors thus insist on the insertion of stabilization clauses in transnational investment agreements, particularly in the oil industry (Emeka 2008). These provisions are aimed at precluding host states from taking legislative or administrative measures, which impede on the commercial interests of the investor (Bernardini 2008). Thus, the State undertakes not to utilize its legislative and administrative prerogatives in a way that will have a detrimental effect on the investor. The agreement may even go on to specify what actions are prohibited. This may include, for example, an undertaking not to raise taxes for a period of time, otherwise referred to as tax stability clauses. These provisions are created for the protection of the investors, because the host government have various mechanisms at their disposal which could potentially jeopardize the foreign investor's legitimate expectations of making a profit out of their investments. They protect the investment by rendering the agreement immune from national law (Mann 1973). The inclusion of these clauses are not just a major concern for investors but also other stakeholders such as lending financial institutions (Maniruzzaman 2009). The lending institutions are typically the ones that will finance the projects. They too will need assurances that they will get their money back from the investor, once they make a borrowing (Ng'ambi 2014).

Stabilization clauses are designed to stabilize or freeze the essential provisions of the agreement by strictly prohibiting any legislative or administrative act which derogates from or is otherwise inconsistent with the provisions of the agreement or the legal environment of the transaction. Stabilization clauses seek to insulate the contract from unilateral alteration. It is therefore a derivate or precipitate of the principle of pacta sunt servanda. Stabilization clauses are directed against: (a) arbitrary increase in taxes; (b) amendment of municipal laws of the host country which may affect the existing agreement; (c) expropriation, nationalization, and any other form of intervention in the enterprise.

\subsection{Types of Stabilization Clauses}

As already highlighted above, investors will invariably insist on the insertion of stabilization clauses in their transnational oil investment agreements. These clauses 'specifically seek to secure the agreement against future government action or changes in law' (Curtis 1988). The clause purports to do so by immunizing the contract from the municipal law by internationalizing it (Maniruzzaman 2005; Fatouros 1980). Thus, at least in the abstract, any alteration in the law should have no effect on the agreement whatsoever if it contains a stabilization clause (Montembault 2003).

There are various types of stabilization clauses. The first type is the 'stabilization clause stricto sensu' 
(Curtis 1988). This clause seeks to ensure that the law existing at the time of the contract will continue throughout the life of the project (Al-Faruque 2006). Such a clause will, in theory, freeze the municipal law of the host State from the day that the contract is concluded until the contract itself expires. An example of such a clause is that contained in the Concession Agreement of 1933 between Iran and the Anglo Iranian Oil Company. It stated that the:

Concession shall not be annulled by the Government and the terms therein contained shall not be altered either by general or special legislation in the future, or by administrative measures or any other acts whatever of the executive authorities (Paasivirta 1990).

This implies, on a broader level, that if any legislative changes are made by the host State same will not in any way alters the rights and obligations contained in the agreement itself. It therefore follows that in the event where there is a conflict between the provisions of the contract and any subsequent legislation, the former will always take precedence (Al-Faruque 2006). Included within this category would be tax stability clauses. Again these simply stipulate that during the stability period, no new taxes will be introduced by the host State that override the incentives that may be contained in the agreement ( $\mathrm{Ng}$ 'ambi 2014).

Another type is the 'intangibility clause' (Curtis 1988). These are provisions within the contract which denote that the contract cannot be altered or abrogated without the mutual consent of the parties (Al-Faruque 2006; Dolzer \& Schreuer 2012). With this type of clause the State does not actually surrender any legislative or administrative prerogatives per se. However, like the stricto sensu clauses, they do seek to prevent the State from unilaterally altering the terms of the contract. An example of such a clause is the one contained in article 17.2 of the Production Sharing Contract of Indonesia between Pertamina and Overseas Petroleum Investment Corporation and Treasure Bay Enterprise Limited which provides that: "This contract shall not be annulled, amended or modified in any respect, except by mutual consent in writing of the parties hereto" (Al-Faruque 2006).

The third type of stabilization clause one might encounter is the 'economic stabilization clause' (AlFaruque 2006). An example of this is contained within the agreement between the Republic of Gabon and Vanco Gabon Ltd. It reads as follows:

[T] he State guarantees to the Contractor, for the duration of the contract, the stability of the financial and economic conditions insofar as these conditions result from the Contract and from the regulations in force on the Effective Date.

These obligations resulting from the Contract shall not be aggravated, and the general and overall equilibrium of the Contract shall not be affected in an important and lasting manner for the entire period of validity hereof. However, adjustments and modification of these provisions may be agreed upon by mutual consent (Al-Faruque 2006).

This type of clause either prohibits the State from passing a law or taking administrative action that render the contract more onerous or expensive to perform or ensures that in an instance where the government does pass such a law the government can examine these adverse economic consequences and restore the economic equilibrium for the investor (Al-Faruque 2006).

\subsection{The Effect of Stabilization Clauses}

There is much academic debate surrounding the precise effect of stabilization clauses (Paasivirta 1990). There are two clearly identifiable categories in this respect. There are those who argue that stabilization clauses do offer absolute protection to the investor on the one hand. On the other hand, there are those who are diametrically opposed to this. $\mathrm{Ng}$ 'ambi, who belongs to the former category, argues that stabilization clauses do offer absolute protection to the investor based on the fact that arbitral tribunals respect the sanctity of contracts thus endorsing maxim pacta sunt servanda. In order to ensure this absolute protection however, investors must also ensure that there is an arbitration clause so that the case is determined in a neutral forum (Ng'ambi 2014).

Stabilization clauses effectively do grant absolute protection to the investor. They purport to do this by circumventing the possibility of an agreement being prematurely terminated or modified by an Act of the legislative arm of the host State (Suratgar 1962). Thus, if a transnational oil investment agreement contains within it a stabilization clause and the host State proceeds to nationalize assets belonging to the investor, then the former would be committing an illegal act.

Stabilization clauses immunize the agreement from municipal law by internationalizing it (De Vries 1984; Coale 2002; Cantegreil 2011). This effectively means that the agreement becomes subject to international law. Therefore, obligations and remedies available to both parties are also of an international character (Amador 
1959). One of those international obligations is the international law principle of pacta sunt servanda. This principle essentially espouses that agreements freely entered into shall be enforced according to their terms (Garner 2004; Carbonneau 1998). This is obviously not an absolute rule (Atiyah \& Smith 2006; Peel 2011). This principle is as applicable to agreements between the host State and private corporations as it is to agreements between the former and other States (Wehberg 1959). Pacta sunt servanda, stems from respect for the sanctity of contracts. It is not an absolute rule. However, the default position is to lean against unilateral termination of existing agreements (Jennings 1961). Thus, once a contract is entered into, its terms must be upheld and respected.

It has been argued that because the contract is 'immune from an encroachment by a system of municipal law', in the same manner as a treaty between two international persons, the contract is elevated to the status of a treaty. For this reason, it is only subject to international law (Mann 1973). This is partly the basis upon which the absolute protection theory has been opposed.

On a conceptual level, arguments abound as to whether a contract with a private investor is equivalent to a treaty. In Amoco International Finance Corp. v Government of the Islamic Republic of Iran (1987)15 Iran-US CT Rep 189, the tribunal took the view that internationalizing a contract is elevating the status of a contract to that of a treaty. Doing so elevates the status of a private corporation to that of a State.

It must however be noted that divergent opinions abound on this issue. This opposition is based on the premise that, by its very definition, a treaty is an agreement between two States. It can never be concluded between a State and an entity, like a multinational corporation which is not a subject of international law. Furthermore, a treaty involves the mutual surrender of sovereign rights and these are rights which the investor does not have the capacity to surrender (Sornarajah 2000; Chatterjee 1988). The clause may stipulate that the proper law of the contract is international law or other general principles of law; however, this does not automatically transform the contract itself into an international agreement within the definition espoused in the Vienna Convention on the Law of Treaties (Schachter 1991; Amerasinghe 1964). These sentiments were reechoed in the case of Saudi Arabia v ARAMCO (1963)27 ILR 165 - 167 where the tribunal rejected the contention that the concession should be assimilated to an international treaty governed by the Law of Nations. It was further held that the law applicable in this case should be that of Saudi Arabia because this is the law of the country with which the contract has the closest natural and effective connection, unless another law is designated by the conclusive conduct of the parties.

A State can limit its legislative powers on account of an international agreement with another State. Thus, generally speaking, if there is a treaty in place and the State violates it through legislative means then this will have international consequences. It does not follow however that a contractual agreement with an individual or corporation can have the same effect (Wolff 1950). It would thus appear that an agreement between a State and a corporation falls outside the scope of the Vienna Convention on Treaties. It therefore, cannot be said to be a treaty or tantamount to one. However, as an exception to this rule, it is now generally accepted that a contract can be elevated to an international level, where there is an umbrella clause in a bilateral investment treaty between the host State and the home State of the investor (Schill 2009).

A further view espoused by opponents to the absolute protection theory is that, private relations are not governed by international law as such. Thus, applying international law to private relations is misplaced and attempting to do so is like trying to apply, 'the matrimonial laws of France or England to relations between cats and dogs' (Sereni 1959). This is a relatively weak argument, considering the myriad sources of international law that private entities are able to rely upon in the modern era (Ng'ambi 2012).

Opponents of the absolute protection theory have simply dismissed it as, "essentially selfserving...designed to support a very partisan, capitalist approach to contractual disputes" (Bowett 1988). Indeed, it has been seen that there are conceptual problems with equating a contract to a treaty. For this reason it is difficult to accept this as a basis for binding a State to agreements which contain stabilization clauses (Ng'ambi 2014). Given these views one might, therefore, hesitate in arriving at the conclusion that stabilization clauses are inherently valid and enforceable (Nwaokoro 2013; Crawford \& Johnson 1986). Although there is no consensus in the academic debate on this matter, it would appear that there are an overwhelming number of cases in support of holding States to undertakings made through stabilization clauses. The basis of this is the sanctity of contracts, as encapsulated by the maxim pacta sunt servanda. This means that all agreements must be upheld. After all, under the principle of the sanctity of contracts, it is the will of the parties that serves as the foundation of their agreement. The insertion of stabilization clauses in agreements in the first place, is an expression of that will and for this reason, stabilization clauses should be upheld (Muchlinski 2007).

\subsection{Stabilization Clauses vis-à-vis Permanent Sovereignty over Natural Resources}

There are doubts as to whether stabilization clauses can limit a State's inalienable prerogatives (Chatterjee 1988). See the decision in Oscar Chinn's Case (1934) PCIJ Series A/B No. 63, 23. One of such prerogatives is the right to nationalize foreign owned property in exercise of State sovereignty (Bernardini 2008). State sovereignty is the 
concept that States are in complete and exclusive control of all the people and property within their territory, and also includes the idea that all States are equal. In other words, despite their different land masses, population sizes, or financial capabilities, all States, ranging from tiny islands of Micronesia to vast expanse of Russia, have an equal right to function as a State and make decisions about what occurs within their own borders. If all States are equal in this sense, then a State does not have the right to interfere with the internal affairs of another State. See the Anglo-Norwegian Fisheries Case (U.K. v Norway) (1951) ICJ Rep 3. The sovereignty of Nigeria as a State is guaranteed by sections 2(1) and 14(1) of the 1999 Constitution of the Federal Republic of Nigeria (as amended). See the decision in the case of Inspector-General of Police v All Nigeria Peoples Party \& Ors (2007)18 NWLR (pt. 1066) 457. Indeed, stabilization clauses appear to be incompatible with the principle of sovereignty of the State in that they purport to impose unlimited constraints on the legislative competence of the host country. Sonarajah supports this view and opines that the acceptance of the principle of permanent sovereignty over natural resources would mean that a State cannot validly agree not to change the terms of an agreement on the exploration of its natural resources (Sornarajah 2010).

It is arguable that a State cannot surrender its sovereign prerogatives because these are often imperative if the State is to function. Thus, it is unclear whether a stabilization clause requiring the subjugation of the State to mandatory rules of international law can produce such typical effect. However, there is a possibility that the reliance induced by the stabilization clause entitles the injured party to compensation for any damage caused by the said nationalization. This should be the case even where the breach of the stabilization commitment is not in itself declared illegal by the arbitral tribunal (Sornarajah 2010; Cotula 2008; Te'llez 2012). Indeed, the decisions of some arbitration tribunals seem to uphold the principle of permanent sovereignty over natural resources in such instances, though such cases are in the minority. An example is the decision in LIAMCO v The Government of the Libyan Arab Republic (1977) ILR 141. Even in this case, the arbitrator acknowledged that ordinarily, the contract could not validly be terminated without the "mutual consent of the contracting parties, in compliance with the said principle of the sanctity of contracts and particularly with the explicit terms of Clause 16 of the Agreements." However, having found that the nationalization was non-discriminatory and for a public purpose, the arbitrator declared it as lawful. Apparently, this view at best constitutes an exception to the general rule of applicability of the principle of pacta sunt servanda to stabilization clauses rather than a parallel rule on its own. Another exception appears to have been created in the case of Aminoil v Kuwait (supra), where it was stated that the overall effect of a stabilization clause is to be determined by considering the object and purpose of the clause in the particular contract. Thus, it may be argued that this case decided that there is no absolute principle on the applicability of stabilization clauses but rather each clause is to be considered on the basis of its own merits, regards being had to the tenure of the contract accommodating the clause. In that case, the tribunal held that the purpose behind the stabilization clause in the agreement was to protect against confiscatory termination and takeover and as such, if the takeover is not confiscatory, it would not amount to a breach of the stabilization clause. Since the government had made an offer of monetary compensation, the tribunal held that taking was not confiscatory and did not amount to a breach. Also, the fact that the clause did not expressly and unambiguously prohibit or limit the right to nationalize and the fact that the duration of the contract was considered unreasonably long (60 years) was taken into consideration by the tribunal in coming to the decision that the stabilization clause did not apply to prevent nationalization. Also, in Amoco International Finance Corp. $v$ Government of the Islamic Republic of Iran (supra), the need for the stabilization clause to expressly prohibit nationalization for same to be declared unlawful was emphasized. Also see EnCana v Republic of Ecuador (2006) LCIA Case UN3481, 49.

On the other hand, it has also been argued that stabilization clauses are valid and do not derogate from the sovereign rights of a State. This appears to be the dominant view, considering the plethora of arbitral cum judicial authorities that have adopted same. See the decisions in Lena Goldfields Arbitration (Case 1) (Lena Goldfields Limited v USSR) (1929-30)5 ADIL 3; Ruler of Qatar v International Marine Oil Company Ltd (1953)20 ILR 534; Revere Copper \& Brass Inc. v Overseas Private Investment Corporation (1978)17 ILM 1321; Methanex Corp v United States of America, Award of 5 August 2005 (at Part IV, Ch D, para 7); ParkeringsCompagniet v Lithuania, Award, 11 September 2007, ICSID Case No. ARB/05/8, para 332. Thus, in Government of Saudi Arabia v Arabian American Oil Co. (1963)27 ILR 117, the arbitral tribunal while rejecting the well canvassed argument that interpreting a stabilization clause so as to preclude the host State from passing certain legislation in the public interest would be an encroachment on the doctrine of permanent sovereignty over natural resources, held that "nothing can prevent a State from binding itself irrevocably... and from granting to the concessionaire irrevocable rights." The effect of the above is that a State cannot go back on its decision once it has renounced the right to exercise some of its powers. Once the State has accepted a stabilization clause it gives the investor a 'legitimate expectation' which the government cannot then go back on, as decided in the case of BP Exploration Co. (Libya) v The Government of the Libyan Arab Republic (1979)53 ILR 297. Thus, the general rule remains that sovereignty cannot be cited as an excuse for the State's failure to fulfill its contractual obligations, as decided in the cases of Texaco Overseas Oil Petroleum Co. \& Anor v The Government of the 
Libyan Arab Republic (supra); AGIP v. Peoples Republic of Congo (1982)21 ILM 726; LETCO v Liberia (1989) 2 ICSID Reports 343.

According to Chowdhury, when a State makes commitments in stabilization clauses, it does so in the exercise of the sovereignty which inheres in it and not in derogation thereof (Hossain \& Chowdhury 1984). Even Koskemeni agreed that "States...had been able to bind themselves because they were sovereigns. If they were not able to bind themselves - and thus receive the benefits they were looking for - then they could not really be sovereigns...." (Koskemeni 2011). In Government of Kuwait v American Independent Oil Co. (1982)21 ILM 976, the tribunal held that the nationalization was arbitrary and awarded damages against the host country. Also, in Texaco Petroleum Co. Ltd \& California Asiatic Oil Co. v The Government of the Libyan Arab Republic (1979)53 ILR 398, the arbitrator awarded damages assessed on the principle of restitutio in integrum. A similar decision was also reached in Sapphire International Petroleum Ltd. v. National Iranian Oil Co. (NIOC) (1967)35 ILR 136

In order to escape the liability which may arise from the breach of a contract, host countries may prefer to insert clauses which will enable them alter their contract with the IOCs. Such clauses may provide that nothing in the contract including any provision on arbitration shall prevent the host country from exercising her inalienable rights.

\section{The Concept of Renegotiation Clause}

In order to make room for flexibility in long-term agreements, renegotiation or review clauses are incorporated into such agreements. Renegotiation clauses are contractual mechanisms which give the parties the option to review, discuss and adapt the terms of a contract. These typically take effect either upon the occurrence of a triggering event or during specific intervals (Gotanda 2003). If the triggering event has the effect of altering the contractual equilibrium that exists between the parties, then there exists the possibility of adapting the contract. This is provided that the parties agree to such adaptation or provided that the clause itself prescribes adaptation by a third party. The legal validity of these clauses is undisputed because they are inserted by the free will of the parties (Al-Faruque 2008).

Renegotiation may be intra-contact, extra-contract, or post-contract. The insertion of a renegotiation clause into the contract facilitates intra-contract renegotiations (Salacuse 2013). This is because they occur within the framework of the agreement itself. This can be contrasted with extra-contract renegotiation, which as the name implies occur outside the framework of the existing agreement. The fundamental feature of these renegotiations is that one party was requesting the alteration of pre-existing contractual obligations even though there was no provision for this in the agreement itself (Salacuse 2013). Post-contract renegotiations occur upon the expiration of the contract. Although the parties, in the abstract, are relieved of their obligations once the contract has elapsed, they may nonetheless attempt to renew their relationship (Salacuse 2013).

\subsection{Difference between Renegotiation Clauses and Stabilization Clauses}

Renegotiation clauses can be contrasted with stabilization clauses. In the latter case the aim is to freeze the law so as to 'keep the original balance alive throughout the contract', whereas in the former case the aim is to keep the relationship alive by 'requiring the parties to strike a new balance wherever there are circumstances justifying a change in the original obligations of the contract' (Sornarajah 2010). The difficulty with rigid contractual arrangements, whether fiscal or otherwise, is that they cannot 'realistically persist in the face of the dynamic economic changes at the global and national level over ten years' (Mato 2012). The contractual framework should reflect this and acknowledge that the possibility of change is a normal and integral feature of international business (Mato 2012). This could be accomplished through the insertion of renegotiation clauses in the contract.

Although it is understandable that the investor would need some form of stability in their contracts, this position cannot be sustained in the long run. Indeed, stabilization clauses on their own cannot withstand the realities associated with long term contracts (Chatterjee 1988). No one questions the necessity of inserting some form of protective clause (i.e. stabilization clause) in the agreements (Foster 2005). However, the vicissitudes of the natural resource industry are a good enough reason to provide for some form of flexibility in long term agreements through renegotiation clauses. This facilitates renegotiations that can be conducted in instances where there are windfall profits or indeed in instances where the economic situation has become so onerous to the investor that they need to revise certain contractual terms to stay afloat. It is in the interests of the parties to renegotiate the contract as their relationship is an interdependent one and their interests inextricably linked (AlFaruque 2008). Renegotiation does not undermine the stability of agreements. It actually provides a form of insurance against the resource nationalism cycle. Governments are more likely to react adversely, if they realize that the contract emphatically excludes the possibility future revision (Mato 2012). There would be far less inclination to nationalize or take any other draconian measures, if the terms of the agreement episodically be revisited, reopened and revised. Asante observes: 
If periodical review is recognized as a realistic feature of the investment process, financiers could take it into account in determining the financing agreements, and the renegotiation could be so timed as to coincide with the year in which the investor would have recouped his investment. Thereafter, both parties could agree on a reasonable rate of return for the investor (Mato 2012).

Despite their differences, the two clauses can co-exist within the same contract (Waelde \& Ndi 1996). The combination may seem incongruous. However, the advantage of having the clause lies in the fact that governments and corporations alike are then under an obligation to renegotiate the contract in good faith, with the aim of restoring the contractual equilibrium.

\subsection{Why Renegotiate?}

The need to renegotiate is influenced by a plethora of factors. Chief among these is the fact that transnational oil investment contracts are long term agreements which, as a general rule, run for periods exceeding ten years. Indeed some may even run for sixty years as was the case in Aminoil v Kuwait (Supra). Regardless of the time frame, it is within the realm of contemplation that episodically a concatenation of circumstances will necessitate the revisiting of certain contractual provisions (Al-Faruque 2008). Such a situation for example may be precipitated by a sudden windfall in commodity prices. There may also be a perception, whether misconceived or not, that multinational corporations are externalizing more profits from the natural resources of the host State than they are actually bringing in. This can further be compounded in instances where the State is in a relatively weaker bargaining position than the corporation (Al-Faruque 2008). The perceived unfairness of this may lead to political strife (Stevens 2008). Indeed, such a situation may lead to two potential consequences. If a friendly host government who may have previously granted favourable terms to the investor is in power they may wish to revisit the terms of the agreement. The incentives received by multinational corporations may possibly be reduced or even revoked so that the party in power may maintain their political hegemony. This is so as to obtain an equitable share of the profits generated by the multinational corporation as a result of the windfall. Such a move would be calculated to pacify an agitated people which in turn would generate the political mileage needed for the government of the day to maintain their political hegemony. The second potential consequence is that the political strife may lead to a change of government through democratic or indeed extra-democratic means. In such an instance the new government may seek to renegotiate the terms of the contract so as to reach a more equitable tax regime. Failure to renegotiate with an overzealous government may potentially lead to the outright nationalization of the investor's assets. The renegotiation clause acts as a buffer against such extreme consequences by aiding the parties in reaching an equitable solution 'which eventually facilitates stability in the contractual relationship by promoting confidence, trust and reliability between them' (Al-Faruque 2008). By inserting renegotiation clauses, the parties are minimizing the chances of a conflict occurring (Gotanda 2003).

It has further been advanced that culture is an influencing factor. Perceptions of how business ought to be conducted vary from culture to culture. Invariably, the business practices of capital exporting nations will be very different to those to the capital importing ones. As a result of this, differences may arise and it may be necessary to renegotiate the terms of the contract.

From the foregoing, it can be seen that renegotiation clauses are mutually beneficial to the host country and the IOCs. Changing circumstances in the world oil market make renegotiations necessary. Renegotiation clauses make for harmonious relations between the parties. Indeed, any modern investment contract, particularly in the oil industry is "an invitation to a ball" and the absence of flexibility in the contract may lead to acrimony.

\subsection{The Renegotiation Process: Issues Arising}

A number of issues arise from the renegotiation. The first element is to identify the circumstances that will lead to a renegotiation. This is what is referred to as the trigger event. The second issue that arises is the effect that the trigger event should have on the contract. The third issue that needs to be identified is the objective of the renegotiation. In other words: what are the parties seeking to achieve through the negotiation? Once these factors have been established, clear guidelines on the procedure for the renegotiation needs to be drawn by the parties. Finally, there must be a solution stipulated in case the parties fail to reach an agreement. This would normally mean referral to a third party to review the matter and possibly alter the terms of the agreement.

\subsubsection{Triggering Event}

The very first issue that must be identified is the event, or indeed concatenation of events, that will activate the process of renegotiation. This is referred to as the triggering event. Once the triggering event is identified, it will become the legal basis upon which the parties may then proceed to renegotiate (Al-Faruque 2008). As we have noted above, some clauses specify the precise events that will trigger a renegotiation. They may for example stipulate tax increases or the fluctuation or depreciation of commodity prices. 
Precision in the language will serve to narrow the instances in which renegotiation between the parties can be initiated. Other clauses may utilize such general terminology as 'a substantial change in the circumstances existing on the date of the agreement' or 'a change of circumstances', thus widening the scope of events that may trigger a renegotiation. Some clauses may not even mention a trigger event at all (Al-Faruque 2008). An example of a clause which does not contain a trigger event is the OK Tedi Clause which utilizes more general terminology when it states, "The parties may from time to time by agreement in writing add to, substitute for, cancel or vary all or any of the provisions of this Agreement" (Al-Faruque 2008).

The advantage of having a narrowly defined clause is that the specificity contained therein leads to certainty which is good for both the State and the investor. This is owing to the fact that clearly defined events will, in theory, circumvent an opportunistic party from requesting renegotiation in instances outside the scope of the terms defined in the contract (Al-Faruque 2008). It is argued that difficulties typically arise in the event where the triggering event is not sufficiently defined in the agreement (Dolzer \& Schreuer 2012). However, there is a danger that the terms can be so stringent that it leads to precisely the type of rigidity identified in stabilization clauses. A wide definition is advantageous in that it allows for some form of flexibility. However, there is also a danger that it can be so wide that it leads to uncertainty. This fact notwithstanding, a wider definition at least allows for the type of flexibility that in the long run will certainly protect the investor's interests whilst protecting the States sovereignty. Furthermore, it is rather difficult to envisage and thus account for every conceivable eventuality in the contract (Bernardini 2008). For this reason it is better to have a wide definition that will capture every reasonable eventuality that may not be envisaged by contractual draftspersons.

The possibility of either of the parties initiating vexatious renegotiations is averted by the fact that arbitral tribunals tend to define the triggering events very narrowly (Al Qurashi 2005). Clearly, this leads to some consternation on the part of both parties, since express contractual language will not totally eliminate the risk (Fox 1998).

\subsubsection{The Effect of the Change on the Contract}

Renegotiation and adaptation clauses apply only in exceptional circumstances (Bernardini 2008). Again this could be defined in the clause itself by determining the effect of the triggering event on the actual relationship of the parties. If the effect on the parties does not manifest, then again there is no legal basis for renegotiation. It could be drafted in a way that the triggering event causes a 'disproportionate prejudice', 'substantial detriment', 'substantial economic imbalance' on the parties' relationship or simply materially affects 'the economic and financial basis of the agreement.' They could also use a term like, 'the consequences and effects of which are fundamentally different to what was contemplated by the parties at the time of entering the agreement' (Bernardini 2008). Neither of the parties may be allowed to demand performance during renegotiation.

\subsubsection{The Objectives of the Parties in Renegotiation}

The precise obligations of the parties in the course of renegotiation must be defined (Bernardini 2008). Subjective wording such as 'removing the unfairness' or 'adopting an equitable revision' may be utilized (Bernardini 2008). Alternatively an objective wording like 'restoring the original contractual equilibrium' can also be used (Ng'ambi 2014). The LASMO clause talks of making 'necessary changes to this Agreement to ensure that the contractor is restored to the same economic conditions which would have prevailed if the new law and/or regulation or amendment had not been introduced' (Berger 2003).

The objectives of either party may be very different. The host government may seek to achieve diverse goals through a renegotiation of the petroleum contract, e.g. to gain greater control of the economy for the government and citizens; to secure an increase in revenue from the project; to promote economic self-reliance; to combat economic imperialism; to implement an ideology; to implement a policy of joint venture between foreign investors and state corporations; to obtain government control of major productive enterprises; to promote state monopolies; or to gain access to new technology, etc (Al-Faruque 2008). The investor may also have their own objectives during the renegotiation process. Their interests may lie in the economic viability of continuing with the contract in its original form. Tied to this, they will also be interested in restoring the equilibrium of the contract. Indeed there may be cases where the investor discovers that a particular find is not as economically viable as initially anticipated. Perhaps they may also seek to renegotiate in instances where the price of a commodity has depreciated. In whatever scenario, just like the host State, the investor will require the terms of the contract to be renegotiated from time to time (Al-Faruque 2008).

\subsubsection{The Procedure for the Renegotiation}

The procedure for the renegotiations should clearly stipulate the parties' obligations (Bernardini 2008). Invariably, renegotiation clauses are cryptic on the actual obligations of the parties. How do the parties thus decipher what these are? It is advanced that regardless of the formulation of the renegotiation clauses the parties can decipher what their obligations are by looking at the inherent functions of the renegotiation clause. These are threefold. The first is to compel the parties to "cooperate in the renegotiation procedure in an efficient manner" (Berger 2003). That is to say that the parties should act in a manner that is aimed at successfully reaching a solution by adopting a flexible attitude and consideration for the needs of the other party (Berger 2003). 
The second function of the clauses is to adapt the contract to, and only to, the changed circumstances (Berger 2003). There is no justification for altering and restructuring the entire contract unless this is actually stipulated in the contract itself. The third function of these clauses is to maintain and control the commercial balance of the contract while adapting it to the changed circumstances (Berger 2003). It should certainly not lead to a situation whereby one party seeks to exploit the other party's weakness so as to obtain a commercial advantage. Thus, the obligations of the parties during the renegotiation process are as follows: (a) keeping to the negotiation framework set out by the clause; (b) respecting the remaining provisions of the contract; (c) having regard to prior contractual practice between the parties; (d) paying attention to the interests of the other side; (e) giving appropriate reasons for one's own adjustment suggestions; (f) making an effort to maintain the priceperformance relationship taking into consideration the parameters regarded as relevant by the parties; and $(\mathrm{g})$ avoiding an unfair advantage or detriment to the other side (i.e. the "no profit - no loss" principle). These factors can serve as a mere starting point in determining the parties' obligations in each case. However, this also has to be determined in conjunction with the actual wording of the renegotiation clause. Further consideration must be paid to the nature of the contract and the intention of the parties (Berger 2003).

\subsubsection{Course of Action Should the Renegotiation Fail}

It is possible for the parties to fail to reach an agreement during the renegotiation process, in which case renegotiation is said to have failed. This is a potential pitfall in having a renegotiation clause in the contract. Clearly, the clause imposes a duty on the parties to negotiate in good faith and same must be concluded within a reasonable period of time. Failure to do this may amount to breach of contract (Peter 1995).

However, even though there is a duty to negotiate, this does not mean that there is an actual obligation for the parties to come to an agreement subsequent to the renegotiation proceedings (Salacuse 2000), as decided in the cases of Railway Traffic Case (Lithuania v Poland), (1931) PCIJ Series A/B No. 42 at 116 and North Sea Shelf Case (1969) ICJ Rep 4 at 47, paragraph 85 . This position was also quite succinctly highlighted by the tribunal in Aminoil v Kuwait (supra) and also in Wintershall A.G. v Qatar (1989)28 ILM 795. In the event that the parties do fail to reach an agreement, it is recommended that the matter be referred to a third party such as an arbitrator. The renegotiation clause itself or the agreement should provide for such referral. The role of the arbitrator would be to examine the matter and then amend the agreement on behalf of the State and the investor.

However, one problem which the parties might face is that arbitrators will be reluctant to adapt the contract unless the parties confer on them the authority to do so. Another problem may arise if the parties go for arbitration at the International Centre for the Settlement of Investment Disputes (ICSID), established by the 1965 Convention for the Settlement of Investment Dispute between States and Nationals of other States (ICSID Convention). Because there needs to be an actual legal dispute, arbitrators may deny jurisdiction in the case at all. This is owing to the fact that failing to agree during the process of negotiation does not necessarily constitute a 'legal dispute' under ICSID.

\subsection{Renegotiation of Contracts without Renegotiation Clause}

Even in the absence of a renegotiation clause in a long term agreement, there still may be alternative avenues through which the host State may realize flexibility in their agreements (Mato 2012). Renegotiation in such situations may be made possible under the principle of clausula rebus sic stantibus, literally meaning 'things thus standing' or better put that 'a fundamental change in basic circumstances of a contract justifies a revision'. This doctrine entitles a party to a treaty/contract to which it applies to escape his obligations by rendering same inapplicable because of a fundamental change in circumstances. See article 62 of the 1969 Vienna Convention on the Law of Treaties. If parties had contemplated the occurrence of the changed circumstance the doctrine does not apply and the treaty/contract remains effective. Clausula rebus sic stantibus only relates to changed circumstances that were never contemplated by the parties. See the Fisheries Jurisdiction Case (United Kingdom $v$ Iceland) (1973) ICJ Rep 3. Under this rule there may be an obligation to renegotiate if there is a change of circumstances. Thus, the principle entails that in the event of an unforeseen change of circumstances that destroys the economic viability of a contract the parties may be permitted to renegotiate the contract or refer the matter to a tribunal for amendment or termination as decided in the case of Establishment of Middle East Country X v South Asian Construction Co. (1987)12 YCA 97, 109. This however contrasts with the position in AMCO Asia v Indonesia (1984)23 ILM 351 and Hungarian State Enterprise v Yugoslav Crude Oil Pipeline (1984)9 YCA 69, 70.

In order to activate and depend on the clausula rebus sic stantibus principle, there must either be a contractual term to this effect or the applicable law must provide for it (Berger 2003). Application of the doctrine varies from jurisdiction to jurisdiction. Two factors however do bring some form of commonality. Firstly, the courts in most jurisdiction respect the fact that pacta sunt servanda is the overriding policy of contract law. Secondly, whilst the courts recognize that clausula rebus sic stantibus is one of the exceptions to this rule, they are only willing to apply it in limited circumstances, thus averting the potential for misuse of the principle (Horn 1995). The principle is thus useful in ensuring equity and justice and protects the legitimate interests of both 
contracting parties. Thus, it is submitted that the principle of clausula rebus sic stantibus is not diametrically opposed to pacta sunt servanda. In fact, the two principles complement each other like two sides of a coin. The former simply tempers the rigidity of the latter by ensuring that contracts are enforced in a more equitable and dynamic manner (Hossain 1980). The approach of the courts is best summed up by Arbitrator Lalive in Indian Cement Co v. Pakistani Bank (1980) ICC Case No. 1512 at 128 - 129 where he opined that:

The principle "rebus sic stantibus" is universally considered as being of strict and narrow interpretation, as a dangerous exception to the principle of sanctity of contracts. Whatever opinion or interpretation lawyers of different countries may have about the 'concept' of changed circumstances as an excuse for non-performance, they will doubtless agree on the necessity to limit the application of the so-called 'doctrine rebus sic stantibus' (sometimes referred to as "frustration", "force majeure", "imprevision", and the like) to cases where compelling reasons justify it, having regard not only to the fundamental character of the changes, but also to the particular type of the contract involved, to the requirements of fairness and equity and to all circumstances of the case.

The principle of fundamental change of circumstances (rebus sic stantibus) is certainly one that is recognized under customary international law, as decided in the Fisheries Jurisdiction Case (United Kingdom v Iceland) (Jurisdictional Phase) (1973) ICJ Rep 3. This principle is found in article 62 of the 1969 Vienna Convention on the Law of Treaties which highlights the grounds upon which a State may withdraw from a treaty. Article 62(1) states that, provided the circumstances were unforeseen a State may withdraw from a treaty in instances where: (a) the existence of those circumstances constituted an essential basis of the consent of the parties to be bound by the treaty; and (b) the effect of the change is radically to transform the extent of obligations still to be performed under the treaty. Article 62(2) further provides the principle may not be invoked in instances where the said treaty establishes a boundary or where the fundamental change is a direct consequence of a breach committed by the invoking party.

Note that the application of the principle of clausula rebus sic stantibus is limited to exceptional cases. Indeed for it to apply, the occurrence of the fundamental changes must not be traceable to the will of the parties. Thus, the emergent event must not be reasonably foreseeable or foreseen by the parties at the time of the contract and also, the emergent event must be capable of rendering the obligation of one party so onerous that if it had been contemplated at the time of the contract the affected party would not have entered the contract, as decided in the Case Concerning the Gabcikovo-Nagymaros Project (Hungary v Slovakia) (1998)37 ILM 162. Though it is arguable that both the Vienna Convention on the Law of Treaties and the Gabcikovo-Nagymaros Project Case dealt only with treaties and not transnational contracts between multinational corporations and the host government, it may nevertheless serve as persuasive authority on the point. Although it is just in draft form, the sentiments expressed in the UN Draft Code of Conduct for Transnational Corporations do provide an indication of the potential direction that the United Nations may eventually go with the principle of rebus sic stantibus as applicable to contracts between host countries and transnational corporations. Article 5 of the aforementioned draft code states that a transnational corporation should respond positively to requests for renegotiation of agreements in instances:

...marked by duress, or clear inequality between the parties, or where the conditions upon which such a contract was based have fundamentally changed, causing thereby unforeseen major distortions in the relations between the parties and thus rendering the contract unfair or oppressive to either of the parties. Aiming at ensuring fairness to all parties concerned, review or renegotiation in such situations should be undertaken in accordance with applicable legal principles and generally recognized legal practices (Horn 1980).

Further evidence of this principle of clausula rebus sic stantibus is also found under the 2016 UNIDROIT Principles of International Commercial Contracts. The Principles, whilst recognizing pacta sunt servanda state that it is not an absolute rule. Article 6.2.2 states that there is an obligation to perform despite the hardship unless "the occurrence of events fundamentally alters the equilibrium of the contract either because the cost of a party's performance has increased or because the value of the performance a party receives has diminished." The events must occur after the conclusion of the contract. Furthermore, the events must not have reasonably been taken into account at the conclusion of the contract and they must be beyond the control of the party seeking excuse. Paragraph (d) further provides that the party should not have assumed the risk of events. The commentary sheds 
more light on what this actually means. It says that even though certain risks may not have been undertaken expressly, the element of risk may be implied from the very nature of the contract. A person that enters a speculative transaction is deemed to assume a certain degree of risk even though he or she is not fully aware of them at the time that the contract is being concluded. In the event of hardship, article 6.2.3 provides that the disadvantaged party is 'entitled to request renegotiations.' Such a request must be made without undue delay and should state the grounds upon which it is made. Paragraph (2) provides that this request for renegotiation does not in itself give the disadvantaged party the right to withhold performance. Paragraph (3) states that in an event where the parties fail to arrive at an agreement, they may take the matter to court. Paragraph (4) lays down that where the courts do find hardship, they may if reasonable either terminate the contract or adapt it "with a view to restoring its equilibrium.' Article 7.1.7 provides for instances of force majeure and states that non-performance of a contract is excused if the party in breach can prove that it was as a result of an impediment beyond his or her control and as a result could not reasonably be expected to have taken that impediment at the time that the contract was being concluded nor could the party have avoid or overcome this impediment or its consequences. If the impediment is only temporary then the party is only excused for a reasonable period of time. The reasonableness of such a timeframe depends on 'the effect of the impediment on the performance of the contract.' Indeed there is also a duty to notify the other party of this impediment and its effect on the ability to perform. Failure to give such notification within a reasonable time frame may render the party in breach liable for any damages resulting from this. Excuse for non-performance is also recognised under article 79(1) of the 1980 Vienna Convention on Contracts for the International Sale of Goods (CISG) which provides that a party may escape liability for failure to perform his or her obligations if the said party can prove that this was as a result of an impediment beyond his or her control and that could not have reasonably been taken into account at the time the contract was being concluded. Furthermore, the party must be unable to avoid or overcome its consequences. See the decision in the case of Scafom International BV v Lorraine Tubes, $19^{\text {th }}$ June 2009 [C.07.0289.N] where the Belgian Supreme Court interpreted this as including force majeure. Thus, if there is an unforeseen change of circumstances which leads to the alteration of the contractual equilibrium, then this might under limited circumstances enable the parties to extricate themselves from performance of their contractual obligations.

Note that the doctrine is somehow similar to the common law doctrine of frustration. Thus, though English common law maintains the principle of pacta sunt servanda, it yet recognizes that there may be instances where a change of circumstances renders the contract impossible to perform. In such an event the contract is said to be frustrated. As was stated by Lord Simon in National Carriers Ltd v Panalpina (Northern Ltd) [1981] AC 675 at 700:

Frustration of a contract takes place when there supervenes an event (without default of either party and for which the contract makes no sufficient provision) which so significantly changes the nature (not merely the expense or onerousness) of the outstanding contractual rights and/or obligations from what the parties could reasonably have contemplated at the time of its execution that it would be unjust to hold them to the literal sense of its stipulations in the new circumstances....

The doctrine of frustration discharges the parties from any duty to perform (Atiyah \& Smith 2006). This event however should not be self-induced, as decided in the case of Maritime National Fish v Ocean Trawlers [1935] AC 524. In addition, it must have been unforeseeable, as decided in Walton Harvey Ltd v Walker \& Homfrays Ltd [1931] 1 Ch 274. It should be noted at this point however, that the doctrine of frustration, like rebus sic stantibus, is only applied in limited circumstances. Moreover, it is established that the mere fact that commercial realities have changed leading to increased costs or an adverse effect on one party's profit making capacity, does not in itself amount to a frustrating event, as decided in the cases of Tennants (Lancashire) Ltd v C S Wilson \& Co Ltd [1917] AC 495 (HL); Davis Contractors Ltd v Fareham Urban District Council [1956] AC 696 (HL); and Tsakiroglou \& Co Ltd v Noblee Thorl GmbH [1962] AC 93 (HL). However, the doctrine of rebus sic stantibus at international law differs from the English common law doctrine of frustration in that whereas renegotiation and adaptation necessarily follow in the former, in the latter case the court does not have the power to modify or amend the contract in the event that they do find that the contract has been frustrated. All they can do is discharge the parties of any pre-existing duty to perform (Treitel 1994).

The English position contrasts slightly with the more liberal approach of the United States of America (Al Qurashi 2005). Section 2-615 of the USA Uniform Commercial Code as well as section 268(2) of the USA Restatement (Second) of the Law of Contracts recognizes the principle of 'commercial impracticability.' This doctrine allows the parties to request a renegotiation in instances where circumstances have altered so radically that performance of the contract is no longer economically viable (Kolo \& Wälde 2000). Indeed, the change of circumstances must be unanticipated at the time that the original contract was being signed and must be so 
financially damaging to the party, with the possibility of even driving the said party to bankruptcy, as decided in Alumnium Co of America v Essex Group Inc, 449 F. Supp. 53 (W.D. Pa. 1980). Although the position in the United States of America is slightly wider than under English Common Law we can see that it is still very narrow.

Judges under the civil law systems appear to be slightly more empowered than their common law counterparts. The general rule is that pacta sunt servanda is the prevailing principle when one contracts under the civil law. However, this rule only subsists if the underlying circumstances which were essential in the conclusion of the agreement continues to exist (Kolo \& Wälde 2000). The principle of rebus sic stantibus applies once there is a fundamental change in circumstances, as the courts find no justification for holding the parties to contracts which were deemed impossible to perform. It does not follow of course that the parties are permitted an easy escape from their contracts. Certain conditions do need to be met and these are encapsulated in the German principle of Störung der Geschäftsgrundlage and the French principle of Imprévison (Kolo \& Wälde 2000).

Paragraph 313 of the German Civil Code propounds the principle of Störung der Geschäftsgrundlage. Under this principle, the parties are no longer bound to their contractual obligations in instances where unforeseen events have led to a drastic alteration of the essential circumstances that subsisted when the contract was formalized. The disrupted economic equilibrium should be so unbalanced that the contract no longer has any real value to the affected party (Markesinis et al. 2006; Mezzacano 2011; Geiger 1974). In contrast to their common law counterparts the German courts do not only have the power to terminate a contract, they can also adapt it in instances of changed circumstances as codified in paragraph 313 of the German Civil Code (Mezzacano 2011).

The principle of rebus sic stantibus is also found in the French doctrine of imprévison (Geiger 1974; Nicholas 1992). It is implied from this theory that contracts between the French government (or an emanation of the same) can only subsist as long as the fundamental circumstances contemplated by the parties are still in existence (Culda 2010). In order for imprévison to arise, two essential requirements must be met: (a) the change of contractual circumstances must not be due to any fault attributable to the debtor; and (b) the contract must not contain any provisions related to the adaptation (indexing or renegotiation) to the new circumstances (Culda 2010). However, this principle in the French context emanates from French administrative law and applies only to administrative contracts concluded with the French government (Hossain 1980; Culda 2010). It does not apply to civil contracts and the French courts have episodically resisted any attempts to extend it to such contracts. This was clearly illustrated in the Canal de Craponne Case where the Cour de Cassation held that, the courts cannot - even in the interest of equity - take into consideration the time and circumstances in order to modify these agreements, and to substitute new clauses for those which have been freely accepted by the parties (Kapwadi 2012). This, it would appear, is in sharp contrast with the German position. Despite the French reluctance to apply this principle to civil contracts, it has been adopted by various other civil law jurisdictions such as Poland (article 269 of the 1932 Polish Civil Code), Italy (articles 1467 - 1469 of the 1946 Italian Civil Code), Greece (article 388 of the Greek Civil Code) and Egypt (article 147 of the Egyptian Civil Code).

From the above positions, it is clear that whilst the legal systems at both international and national level recognize the principle of rebus sic stantibus, they are only willing to apply it in limited circumstances so as to preserve the sanctity of contracts and other agreements entered into. Thus it is by no means certain that the contracts will be adapted by the courts. Therefore, if a contract is to have any guaranteed form of flexibility, it must be in the form of a contractual clause permitting the renegotiation and adaptation of the terms of the agreement. These clauses would be the mechanism through which renegotiation is facilitated between the host state and the investor (Hossain 1980).

\section{Political Risk Insurance}

One of the means through which investors can protect themselves against political risks which may bedevil investments particularly in the oil industry is through political risk insurance. Such insurance schemes include the Overseas Private Insurance Corporation (OPIC) and the Multilateral Investment Guarantee Agency (MIGA). There are also a number of private insurers such as the American Insurance Group (AIG), Lloyds of London, Sovereign Risk Insurance Limited, Chubb and Zurich Emerging Markets Solution (Maniruzzaman 2005).

OPIC operates with the backing of the government of the United States of America (Inniss 2010). It is required to operate on self-sustaining basis. As a result of this, the organization has recorded a profit for every year since its inception. The OPIC 'helps U.S.A businesses invest overseas, fosters economic development in new and emerging markets, complements the private sector in managing risks associated with foreign direct investment, and supports U.S.A foreign policy.' An advantage with OPIC is that it insures an investors assets for up to twenty years, which is longer than its private counterparts. It may also authorize loans (Inniss 2010).

MIGA operates under the auspices of the World Bank. It commenced operations in 1988 and has about 155 members. Article 2 of the 1985 Convention Establishing the Multilateral Investment Guarantee Agency (MIGA Convention) states that the main reason for the establishment of MIGA is to encourage the flow of investment to 
developing countries. Article 11 of the MIGA Convention covers non-business risks such as nationalization, war or civil disturbance, breach of contract and any losses arising from any introduction of restrictions on the transfer of currency outside the host country by the government. Eligible investments are specified under article 12 of the MIGA Convention and include: equity interests, non-equity direct investment and any medium or long term forms of investment. Moreover, the investment must be made into a developing country as per article 14 of the MIGA Convention.

\section{Hardship Clauses}

The parties could also rely on hardship clauses, if these are contained in the transnational oil investment agreement. These are utilized for different purposes in contracts. Typically, the purpose of these clauses is to deal with any potential hardships that may arise provided they are beyond the contemplation or control of the parties. When such eventualities arise, it gives the parties the right to request the suspension or termination of the contract (Konarski 2003). An example of a hardship clause is the ICC Model Hardship Clause, viz:

1. A party to a contract is bound to perform its contractual duties even if its events have rendered performance more onerous than could reasonably have been anticipated at the time of the conclusion of the contract.

2. Notwithstanding paragraph 1 of this Clause, where a party to a contract proves that:

(a) the continued performance of its contractual duties has become excessively onerous due to an event beyond its reasonable control which it could not reasonably have been expected to have taken into account at the time of the conclusion of the contract; and that

(b) it could not reasonably have avoided or overcome the event or its consequences, the parties are bound, within a reasonable time of the invocation of this Clause, to negotiate alternative contractual terms which reasonably allow for the consequences of the event.

3. Where paragraph 2 of this Clause applies, but where alternative contractual terms which reasonably allow for the consequences of the event are not agreed by the other party to the contract as provided in that paragraph, the party invoking this Clause is entitled to termination of the contract (ICC 2003).

It must be noted that these types of clauses are not so popular in transnational oil agreements (Horn \& Kröll 2004). This is owing to the fact that investors feel that they lead to contractual instability and may provide an easy avenue through which the host State may evade its contractual responsibilities (Horn \& Kröll 2004). Because, in their view, the term hardship cannot be defined with great precision, such a clause may lead to a situation whereby the parties to the contract will excuse their non-performance of a contract, by invoking, inducing or advancing the most spurious of claims (Horn \& Kröll 2004). Such resistance has subsided somewhat over the years (Horn \& Kröll 2004), as decided in the case of Lemire v Ukraine (2002) YBCA 133 at 136. Hardship clauses are also problematic if they provide for termination of the agreement when the hardship occurs. Termination is not an appropriate remedy for transnational oil agreements due to the fact that the investor has, by the time the hardship takes place, invested considerable sums of money on the project and supporting infrastructure (Horn \& Kröll 2004).

Furthermore, rebus sic stantibus seems to apply more in instances where the parties are experiencing severe hardship or serious detriment arising from the changed circumstances. From the wording of the ICC Model Hardship Clause and the general principles applying to frustration, force majeure, imprévision and Störung der Geschäftsgrundlage, one would conceive that hardship clauses only apply to instances where the parties are experiencing some sort of hardship (not necessarily of such a degree required for the application of rebus sic stantibus). For these reasons it is more prudent for the parties to insert renegotiation clauses in their contract.

\section{Dispute Settlement Clause (Mediation and Arbitration)}

One of the concerns of the investor is having their disputes heard by a non-neutral forum such as the national courts, if a dispute was to arise with the host State (Sornarajah 2000). This is owing to the fact that the national courts, in developing countries at least, may not be fully independent of the executive. It is therefore within the realm of possibility that the national courts will render a decision against the investor even in the face of 
incontrovertible evidence. One way to avert this is through the insertion of a dispute resolution clause which provides for arbitration or mediation ( $\mathrm{Ng}$ 'ambi 2014). The clause could even provide that the mediation or arbitration be embarked on where the parties fail to reach an agreement during renegotiation. Even in the absence of such a clause in the agreement, the parties may decide, either with or without a prior attempt at renegotiation, to submit their dispute to mediation or arbitration.

Mediation is a non-binding procedure which attempts to bring the parties together. This is fostered by a neutral third party, the mediator, who assists the parties in reaching their own decision. The advantage with this approach is that it brings the parties together, which in the long run makes it easier to engage in long term business transactions with one another. The difficulty with this approach however, is that is non-binding and therefore the parties can easily depart from any solutions propounded during the mediation proceedings (Ng'ambi 2014).

Another means through which the parties can resolve their disputes is through arbitration. Here, the dispute is heard by an individual or panel of individuals called the arbitral tribunal ( $\mathrm{Ng}$ 'ambi 2014). The tribunals obtain their jurisdiction from the arbitration clause (where one exists in the agreement) or from the terms of their appointment (where there is no arbitration clause in the agreement). The advantage with a decision rendered by a tribunal is that it is binding and enforceable (Ng'ambi 2014). Thus, in Company Z (Republic of Xanadu) $v$ State Organization ABC (Republic of Utopia) (1983)8 YB Comm Arb 94, it was held that the arbitration clause is binding on the State. It was further held that an arbitral tribunal rendering an award in favour of the investor in no way encroaches upon the host State's sovereign right to alter its policies as it saw fit. This is owing to the fact that the tribunal did not claim the power to order specific performance; they only had the power to compel payment of an amount of compensation equivalent to performance.

If the parties had attempted renegotiation and failed to reach an agreement thereat, the arbitrator may consider the terms of the contract and decide whether the conditions set out in the contract for renegotiation have been met. Where the arbitrator finds that the conditions have not been met, then in the abstract the agreement would continue in full force. The term 'abstract' is used in view of the political realities of failure to adapt contracts that are perceived to be unfair. If however, the arbitrator finds that the conditions have been met, then three potential solutions could be propounded: (a) the arbitrator may ask the parties to go back and renegotiate the terms of the contract based on his or her findings; or (b) the arbitrator may simply terminate the agreement; or (c) the arbitrator may adapt the contract in a way that restores the contractual equilibrium (Ng'ambi 2014).

The first two options are well within the scope of the arbitral tribunal's competence. However, with respect to the third solution stated above, it must be emphasized that the powers of the tribunal are contingent on the authority they have been granted by the parties themselves, either through the medium of the arbitration clause in the contract, some subsequent agreement, or the terms of appointment of the arbitrator(s). Arbitral tribunals that have not been granted the authority to amend a contract on behalf of the parties cannot, as a general rule, do so since the express consent of the parties will required before the arbitral tribunal can move to adapt a contract (AlFaruque 2008). This was certainly the position of the arbitral tribunal in Aminoil v Kuwait (supra). In this case, article 9 which contained the renegotiation clause stated as follows: "If as a result of changes in the terms of concessions now in existence or as a result of the terms of concessions granted hereafter, an increase in benefits to Governments in the Middle East should come generally to be received by them, the Company shall consult with the Ruler whether in the light of all relevant circumstances, including the conditions in which operations are carried out, and taking into account all payments made, any alterations in the terms of the agreements between the Ruler and the Company would be equitable to the parties."

However, note that under the kompetenz-kompetenz rule, arbitrators are able to determine their own jurisdiction, as decided in the case of Texaco $v$ Libya (supra). That is to say, it is for them to decide whether or not they have the authority to determine a matter. Thus, article 16(1) of the UNCITRAL Model Law on International Commercial Arbitration states that: "The arbitral tribunal may rule on its own jurisdiction, including any objections with respect to the existence or validity of the arbitration agreement." The applicability of this rule, however, will depend on the arbitration clause itself coupled with the substantive law elected by the parties. The issue of jurisdiction is particularly important because if the arbitrators go beyond the scope of the powers conferred upon them, then this is a ground upon which the award may be refused recognition and enforcement. This rule is contained in article $\mathrm{V}(1)(\mathrm{c})$ of the 1958 Convention on the Recognition and Enforcement of Foreign Arbitral Awards (the New York Convention). Once an award is rendered unenforceable by a competent authority under the law of the seat of the arbitration it makes it difficult, though not impossible, to seek recognition and enforcement in other jurisdictions. The process of seeking recognition and enforcement of non-domestic or foreign arbitral awards is fostered through the Convention on the Recognition and Enforcement of Foreign Arbitral Awards (the New York Convention). Article V(1)(e) of the 1958 'New York Convention' states that an award may be refused recognition and enforcement if it has been set aside or suspended by a competent authority of the country in which, or under the law of which, that award was made. As a result of this, potentially the parties may be foreclosed from seeking recognition and enforcement in other 
jurisdictions (Russi 2008).

However, the term 'in which or under the law of which' as used in article V(1)(e) of the 1958 'New York Convention' is somewhat ambiguous (Russi 2008). This is especially so in instances where the actual seat of the arbitration differs from the applicable procedural law. Suppose for example that the parties select Country A as the seat of arbitration and the law of Country B to govern proceedings. It may be possible for the arbitrator to adapt contracts under the law of Country B but perhaps not possible to do so under the law of Country A. The predicament here is that if the award is set aside by a court in Country A it may be difficult to seek recognition and enforcement elsewhere because of the 'trump card' under article V(1)(e) of the 1958 'New York Convention'. This can occur despite the fact that the procedural law selected by the parties does in fact permit adaptation. As such this effectively frustrates the parties' choice of procedural law and leaves them with an unenforceable award despite the fact that they have strictly adhered to this procedural law (Russi 2008).

This position is further compounded by the fact that the interpretation of the term "foreign award" varies from jurisdiction to jurisdiction. This is because of the rather open-ended definition propounded under the 1958 'New York Convention'. Indeed, article I(1) of the 1958 'New York Convention' states that foreign awards are those which either are made in the territory of a State other than the State where the recognition and enforcement of such awards are sought or those which are not considered as domestic awards in the State where their recognition and enforcement are sought. This may lead to a plethora of unreasonable outcomes. Country A may consider awards rendered in its territory but under a different procedural law as 'non-domestic.' Country B on the other hand may consider only awards made within its jurisdiction as domestic regardless of the applicable procedural law. Thus, an award rendered in Country A but under the procedural law of Country B may be considered as 'non-domestic' by both. Conversely, an award rendered in Country B under the law of Country A may be considered as domestic by both. Now in the latter situation, supposing the award was upheld in Country A but set aside in Country B; recognition and enforcement may still be difficult to attain in other jurisdictions again despite strict adherence to the procedural law selected by the parties. Because of the confusion and fragmentation that this leads to, it should not be left to individual States to decide what is domestic and what is not (Russi 2008).

In order to determine whether an award is domestic or not it is proposed that the law should focus more on the procedural law and not on the seat of the arbitration (Russi 2008). Only the country whose law is chosen should be allowed to set aside the award. That way, the 1958 'New York Convention' is interpreted in accordance with the object and purpose of those that drafted it. The intention of the Convention was to ensure that awards are recognized in as many jurisdictions as possible. The idea that we should focus on the procedural law was also endorsed in the American case of Bergesen v Joseph Muller Corp 710 F.2d 928 (2d Cir. 1983) where the U.S.A District Court stated that awards not considered as domestic denotes awards made within the legal framework of another country.

If the parties elect to settle the matter under ICSID, there are questions as to whether the arbitrator has the competence or jurisdiction to adapt the contract in instances of changed circumstances (Bernardini 2008; Horn \& Kröll 2004). This is owing to article 25 of the 1965 'ICSID Convention' which discusses the jurisdiction of the ICSID tribunal. That is to say, it is the provision which stipulates, 'the limits within which the provisions of the Convention will apply and the facilities of the Centre will be available for conciliation and arbitration proceedings' (IBRD 1965). Under article 25(1) of the 1965 'ICSID Convention', the tribunal's jurisdiction extends to 'any legal dispute arising directly out of an investment.' Therefore, it is clear from the foregoing provision, that the matter before the ICSID tribunal must constitute a 'legal dispute' in order for the tribunal to accept it. If it does not amount to a legal dispute, then this would be a ground upon which any award rendered can be annulled under article 52(1)(b) of the 1965 'ICSID Convention'. The said provision states, that an award may be annulled where the tribunal manifestly exceeds its powers. Once this occurs, the award loses its binding force and as a consequence cannot be enforced in the territory of any contracting State under article 53(1) of the 1965 'ICSID Convention'.

The question that therefore arises is whether a failure to reach an agreement on the revision of specific terms of the contract, subsequently to renegotiation proceedings actually constitutes a legal dispute under the ICSID Convention. The difficulty is that the term was not defined in the 1965 'ICSID Convention'. In defining the term 'legal dispute', ICSID tribunal in the case of Maffezini v Spain (2001)16 ICSID Rev-FILJ 212 at 245 relied on the definition propounded by the ICJ (Schreuer 2001) in the cases of Mavrommatis Palestine Concessions Case (Greece v Great Britain) (1924) PCIJ (Ser. A) No. 2, 11 and Case concerning East Timor (Portugal v Australia) (1995) ICJ Rep 90 wherein the ICJ had held that a legal dispute occurs when there is, "a disagreement on a point of law or fact, a conflict of legal views or interests between parties." Attempts at clarifying what was intended by those that drafted the 1965 'ICSID Convention' were also made in the Report of the Executive Directors submitted to member governments in 1965. Here, it was stated that:

The expression 'legal dispute' has been used to make clear that while conflicts of rights are within the jurisdiction of the 
Centre, mere conflicts of interest are not. The dispute must concern the existence or scope of a legal right or obligation, or the nature or extent of the reparation to be made for breach of a legal obligation (IBRD 1965; Bernardini 2008).

The views expressed in the report are accentuated by those of Delaume. In his view, reference to a legal dispute limits the scope of the arbitrator's jurisdiction to a review of the contractual rights and obligations of the parties in the light of the applicable law. In his view, issues such as non-performance or interpretation of the agreement would fall within the scope of the term 'legal dispute.' However, he goes on to say that, 'disputes regarding conflicts of interest between the parties, such as those involving the desirability of renegotiating the entire agreement or certain of its terms, would normally fall outside the scope of the Convention' (Delaume 1984). The consequences of this are far reaching. It is clear that if the parties fail to agree that the conditions necessitating the renegotiation process have actually occurred, as per the clause, then this constitutes a legal dispute. This is owing to the fact that this is a disagreement concerning the legal rights and obligations of the parties. Thus any dispute of the sort can be characterized as legal. In a similar vein, if following the unsuccessful renegotiation, one party feels the contract should subsist under the old terms and another feels that it ought to be terminated, then this too may constitute a legal dispute. Where the difficulty comes however, is if the parties fail to come to a consensual revision of the terms without fault on either side. In such a case, the arbitrator may be asked to intervene in a matter that does not exactly constitute a legal dispute (Bernardini 1998).

It is recommended therefore, that if the parties are to choose ICSID as the means through which they will settle all disputes arising out of the contract, they should in addition to this allocate the responsibility of adaptation to a third party operating outside of the mechanisms established under the 1965 'ICSID Convention' (Bernardini 1998). The 1965 'ICSID Convention' itself remains applicable in all other respects of the dispute except adaptation. Thus, if a dispute arises the parties still have recourse to the ICSID tribunal (Bernardini 2008). The advantage of such an approach is that it averts problems of jurisdiction and affords the parties the necessary flexibility needed to draft a renegotiation provision that is congruous with the specific needs of the parties.

The point must be made that where the host State unilaterally terminates a contract containing an arbitration clause, the clause itself will continue to subsist (Rosen 1993). This is owing to the principle of separability which establishes the rule that the arbitration clause embedded in a contract is considered as separate from the main contract (Rosen 1993). Therefore, even if the main contract elapses or is voided, the general rule is that the arbitration clause itself continues to subsist. A State cannot therefore prevent being subjected to arbitration proceedings by simply terminating the contract (Ng'ambi 2014). In Libyan American Oil Company (LIAMCO) $v$ Libya (1981)20 ILM 1 at 40, the arbitrator, Mahmassani observed thus:

It is widely accepted in international law and practice that an arbitration clause survives the unilateral termination by that State of the contract in which it is inserted and continues in force even after that termination. This is a logical consequence of the interpretation of the intention of the contracting parties, and appears to be one of the basic conditions for creating a favourable climate of foreign investment.

Supplementing the arbitration clause could be a choice of law clause. This is a particularly sensitive legal issue because it would involve two conflicting interests (Dolzer \& Schreuer 2012). On the one hand the State is interested in preserving and protecting its national sovereignty. On the other hand the investor wishes to choose a legal order that is stable and predictable (Dolzer \& Schreuer 2012). Depending on the bargaining power of the parties there are a few possible outcomes. The choice of law clause could refer exclusively to the law of the host State. Alternatively, the parties could choose a law which operates outside the fray of the national law of the host State. They could for example choose international law or the law of some other jurisdiction. Another potential alternative is the selection of a combination of both national and international law (Dolzer \& Schreuer 2012).

\section{Conclusion}

It has been seen that the discourse of foreign direct investment invariably involves long term agreements between the host State and the foreign investor. Pursuant to the agreement, the investor can utilize his capital to explore and exploit the host State's natural resource. The former then pays royalties and taxes to the latter. It has been seen however, that the long term nature of these agreements renders the investor susceptible to various risks, one of which is the resource nationalism cycle. This cycle begins when the host State, lacking in capital and expertise, will often solicit the aid of foreign investors. The latter in turn brings in the necessary capital, new technology and know-how to commence operations. It is the expectation of the investor to make a profit from the sunk investment. However, it has been seen that once operations commence, and the natural resource experiences a sustained upward trend, the host State will seek to exercise greater control over the natural resource. They do so because they wish to maximize the benefits from the exploitation of their natural resource. 
In the quest to provide a balance between such competing interests, investors usually will demand for the provision of certain clauses in the contract aimed at guaranteeing a stable environment for the realization of the contract.

The general consensus among the arbitral awards is that stabilization clauses are binding upon the State. Failure to abide by this will have consequences. Thus, the principle of permanent sovereignty over natural resources does not override pacta sunt servanda. Entering into contracts is an act of sovereignty. The State cannot then invoke this very principle to prematurely exit these contracts. The difficulty with this however, is that it leads to contractual rigidity which is potentially insalubrious. Indeed, whilst the consequences of breaching a stabilization clause are a good deterrent to unscrupulous behaviour on the part of the State, one might argue that it is in the common interest of both parties to keep the investment going. The prices of natural resources are mercurial and industry patterns are likely to evolve. In either case, circumstances will change and the parties will inevitably have to change with them.

Good a thing, there are other devices which parties could contrive towards infusing some stabilizing flexibility into the contract. These include the renegotiation clause, political risk insurance, hardship clauses and dispute settlement clauses. It is advocated that contractual mechanisms are inserted which in turn will render the agreement more flexible. Even in the absence of such clauses, the flexibility afforded by renegotiation and adaptation of contracts may still be achieved under the principle of rebus sic stantibus.

However, the difficulty with relying on the principle of rebus sic stantibus lies in the fact that it is applied only in limited circumstances. Besides, while the legal system in some jurisdictions allows the courts the power to adjust the contracts under this principle, the courts in other jurisdictions may only be empowered to terminate the contract altogether. These myriad of possibilities and uncertainties lead to the conclusion that inserting renegotiation and adaptation clauses in the agreements may be the best way forward. The renegotiation clause should also stipulate what must happen if the renegotiation process fails. Where parties opt for arbitration, whether without or after an attempt at renegotiation, the arbitral tribunal should also be given the power to adapt the terms of the contract. Without such authority, there is a possibility that the award can be set aside under the 1958 'New York Convention', or annulled under the 1965 'ICSID Convention'. The flexibility facilitated by renegotiation and adaptation is necessary as it is the best means of simultaneously preserving the State's right to pursue legitimate public functions whilst still protecting the legitimate expectations of the investor.

\section{References}

Akinsanya, A. (1978), "Permanent Sovereignty Over Natural Resources and the Future of Foreign Investment", Journal of International Studies 7, 124.

Al Qurashi, Z. (2005), "Renegotiation of International Petroleum Agreements", Journal of International Arbitration 22, 261

Al-Faruque, A. (2006), "Validity and Efficacy of Stabilization Clauses: Legal Protection vs Functional Value", Journal of International Arbitration 23, 317.

Al-Faruque, A. (2008), "Renegotiation and Adaptation of Petroleum Contracts: The Quest for Equilibrium and Stability", Journal of World Investment and Trade 9, 113.

Amador, F.V.G. (1959), "Fourth Report on State Responsibility", Yearbook of the International Law Commission 2, 32 .

Amerasinghe, C.F. (1964), "State Breaches of Contracts with Aliens and International Law", American Journal of International Law 58, 881.

Asante, S.K.B. (1979), "Restructuring Transnational Mineral Agreements", American Journal of International Law 73, 335.

Atiyah, P.S. \& Smith, S.A. (2006), Atiyah's Introduction to the Law of Contract (6 ${ }^{\text {th }}$ edn, Oxford: Oxford University Press).

Barrera-Hernándes, L. (2006), "Sovereignty over Natural Resources under Examination: The Inter-American System for Human Rights and Natural Resource Allocation", Annual Survey of International and Comparative Law 12, 43.

Baxter, R.R. (1980), "International Law in Her Infinite Variety”, International and Comparative Law Quarterly 29, $549-564$.

Berger, K.P. (2003), "Renegotiation and Adaptation of International Investment Contracts: The Role of Contract Drafters and Arbitrators", Vanderbilt Journal of Transnational Law 36, 1359.

Bernardini, P. (1998), "The Renegotiation of the Investment Contract", Foreign Investment Law Journal 13, 411.

Bernardini, P. (2008), "Stabilization and Adaptation in Oil and Gas Investments", Journal of World Energy Law and Business 1, 98.

Bleicher, S.A. (1969), “The Legal Significance of Re-citation of General Assembly Resolutions", American Journal of International Law 63, 444.

Bowett, D.W. (1988), "State Contracts With Aliens: Contemporary Developments on Compensation for 
Termination or Breach", British Yearbook of International Law 49, 49.

Cantegreil, J. (2011), "The Audacity of the Texaco/Calasiatic Award: Rene-Jean Dupuy and the Internationalization of Foreign Investment Law", European Journal of International Law 22, 441.

Carbonneau, T.E. (1998), Lex Mercatoria and Arbitration: A Discussion of the New Law Merchant (2 ${ }^{\text {nd }}$ rev. edn, Boston: Kluwer).

Chatterjee, S.K. (1988), "The Stabilization Clause Myth in Investment Agreements", Journal of International Arbitration 5, 97.

Coale, M.T.B. (2002), "Stabilisation Clauses in International Petroleum Transactions", Denver Journal of International Law and Policy 30, 217.

Comeaux, P. \& Kinsella, S. (1994), "Reducing Political Risk in Developing Countries: Bilateral Investment Treaties, Stabilization Clauses, and MIGA \& OPIC Investment Insurance”, New York Law School Journal of International and Comparative Law 15, 1.

Cotula, L. (2008), "Reconciling Regulatory Stability and Evolution of Environmental Standards in Investment Contracts: Towards a Rethink of Stabilization Clauses", Journal of World Energy Law \& Business 1, 158.

Crawford, J. (2006), The Creation of States in International Law ( $2^{\text {nd }}$ ed, Oxford: Oxford University Press).

Crawford, J.F. \& Johnson, W.R. (1986), "Arbitrating with Foreign States and their Instrumentalities", International Financial Law Review 5, 11.

Culda, S. (2010), “The Theory of Imprévison", Fiat Iustitia 52, 41.

Curtis, C.T. (1988), “The Legal Security of Economic Development Agreements", Harvard International Law Journal 29, 317.

de Arechaga, E.J. (1978), "State Responsibility for the Nationalization of Foreign Owned Property", New York University Journal of Law and Politics 11, 179.

de Sá Ribeiro, M.R. (2009), "Sovereignty Over Natural Resources, Investment Law and Expropriation: The Case of Bolivia and Brazil”, Journal of World Energy Law \& Business 2, 129.

De Vries, H. (1984), “The Enforcement of Economic Development Agreements with Foreign States", University of Detroit Law Review 62, 1.

de Wart, P., Peters, P. \& Denters, E. (1988), International Law and Development (Dordrecht: Martinus Nijhoff).

Delaume, G.R. (1984), "ICSID Arbitration: Practical Considerations", Journal of International Arbitration, 101.

Dolzer, R. \& Schreuer, C. (2012), Principles of International Investment Law (2 ${ }^{\text {nd }}$ edn, Oxford: Oxford University Press).

Dufrense, R. (2004), “The Opacity of Oil: Oil Corporations, Internal Violence, and International Law”, New York University Journal of International Law and Politics 36, 331 - 354.

Duriugbo, E. (2006), "Permanent Sovereignty and Peoples' Ownership of Natural Resources in International Law”, George Washington International Law Review 38, 33.

Emeka, J.N. (2008), “Anchoring Stabilization Clauses in International Petroleum Contracts", International Lawyer 42, 1317.

Fatouros, A.A. (1980), "International Law and the Internationalized Contract", American Journal of International Law 74, $134-141$.

Foster, G.K. (2005), "Managing Expropriation Risks in the Energy Sector: Steps for Foreign Investors to Minimize their Exposure and Maximize Prospects for Recovery when Takings Occur", Journal of Energy \& Natural Resources Law 23, 36.

Fox, W. (1998), International Commercial Agreements: A Primer on Drafting, Negotiating and Resolving Disputes (The Hague: Kluwer Law International).

Gao, Z. (1994), International Petroleum Contracts: Current Trends and New Direction (London: Graham \& Trotman/Martinus Nijhoff).

Garner, B.A. (2004), Blacks Law Dictionary ( $8^{\text {th }}$ edn, Minnesota: West Academic).

Geiger, R. (1974), "The Unilateral Change of Economic Development Agreements", International and Comparative Law Quarterly 23, 78.

Gess, K.N. (1964), "Permanent Sovereignty over Natural Resources: An Analytical Review of the United Nations Declaration and its Genesis", International and Comparative Law Quarterly 13, 398.

Gotanda, J.Y. (2003), "Renegotiation and Adaptation Clauses in International Contracts Revisited", Vanderbilt Journal of Transnational Law 36, 1461.

Horn, N. \& Kröll, S.M. (2004), Arbitrating Foreign Investment Disputes (The Hague: Kluwer Law International). Horn, N. (1980), Legal Problems of Codes of Conduct for Multinational Enterprises (Deventer: Kluwer).

Horn, N. (1995), Adaptation and Renegotiation of Contracts in International Trade and Finance (London: Kluwer).

Hossain, K. \& Chowdhury, S.R. (1984), Permanent Sovereignty over Natural Resources in International Law (London: Frances Pinter).

Hossain, K. (1980), Legal Aspects of the New International Economic Order (London: Frances Pinter). 
Humphreys, M., et al. (2007), Escaping the Resource Curse, (New York: Columbia University Press).

Hyde, J.N. (1956), "Permanent Sovereignty over Natural Wealth and Resources", American Society of International Law 50, 854.

IBRD (1965), Report Of The Executive Directors, On The Convention On The Settlement Of Investment Disputes Between States And Nationals Of Other States, available at $<$ https://icsid.worldbank.org/ICSID/StaticFiles/basicdoc/partB.htm> Last accessed on 02/06/2021.

ICC (2003), ICC Force Majeure Clause 2003 (Paris: ICC Publishing).

Inniss, A.B. (2010), “Rethinking Political Risk Insurance: Incentives for Investor Risk Mitigation”, Southwestern Journal of International Law 16, 477.

Jennings, R.Y. (1961), "State Contracts in International Law", British Yearbook of International Law 37, 156.

Johnson, D. (1994), International Petroleum Fiscal Systems and Production Sharing Contracts (Tulsa: PennWell Publishing Company).

Kapwadi, L. (2012), "Renegotiating a Long Term Investment Contract: The Case of Mining Contracts in DRC", (Unpublished LLM Thesis, University of Pretoria).

Kolo, A. \& Wälde, T.W. (2000), "Renegotiation and Contract Adaptation in International Investment Projects: Applicable Legal Principles and Industry Practices", Journal of World Investment and Trade 1, 5.

Kolo, A. (1994), Managing Political Risk in Transnational Investment Contracts, (Dundee: CPMLP Professional Paper).

Konarski, H. (2003), "Force Majeure and Hardship Clauses in International Contractual Practice", International Business Law Journal 4, 405.

Koskemeni, M. (2011), "What Use for Sovereignty Today”, Asian Journal of International Law 1, 61 - 70.

Lowenfeld, A. (2003), "Investment Agreements and International Law", Columbia Journal of Transnational Law 42, 123.

Maniruzzaman, A.F.M. (2001), "International Development Law as Applicable Law to Economic Development Agreements: A Prognostic View", Wisconsin International Law Journal 20, 1 - 23.

Maniruzzaman, A.F.M. (2005), "Some Reflections On Stabilization Techniques in International Petroleum, Gas and Mineral Agreements", International Energy Law and Taxation Review 4, 96.

Maniruzzaman, A.F.M. (2007), "Drafting Stabilization Clauses in International Energy Contracts: Some Pitfalls for the Unwary", International Energy Law and Taxation Review 2, 23.

Maniruzzman, A.F.M. (2009), "The Issue of Resource Nationalism: Risk Engineering and Dispute Management in the Oil and Gas Industry", Journal of Oil and Gas Law 5, 79.

Mann, F.A. (1973), Studies in International Law (Oxford: Clarendon Press).

Markesinis, B.S., Unberath, H. \& Johnston, A. (2006), The German Law of Contract: A Comparative Treatise ( $2^{\text {nd }}$ edn, Oxford: Hart Publishing).

Mato, H.T. (2012), "The Role of Stability and Renegotiation in Transnational Petroleum Agreements", Journal of Politics and Law 5(1), March Issue, 33 - 43.

Mezzacano, P.J. (2011), "Force Majeure, Impossibility, Frustration \& the Like: Excuses for Non-Performance; the Historical Origins and Development of an Autonomous Commercial Norm in the CISG", Nordic Journal of Commercial Law 1, 48.

Miranda, L.A. (2012), “The Role of International Law in Intrastate Natural Resource Allocation: Sovereignty, Human Rights, and People-Based Development", Vanderbilt Journal of Transnational Law 45, 785.

Montembault, B. (2003), "The Stabilization of State Contracts Using the Example of Oil Contracts: A Return of the Gods of Olympia”, International Business Law Journal 6, 593.

Moran, T. (1998), Managing International Political Risk (Massachusetts: Blackwell).

Muchlinski, P.T. (2007), Multinational Enterprises and the Law ( $2^{\text {nd }}$ edn, Oxford: Oxford University Press).

Ng'ambi, P.K.M.S. (2014), "The Resource Nationalism Cycle, Stabilization Clauses and the Need for Flexibility in Concession Agreements", available at $<$ https://lra.le.ac.uk/bitstream/2381/31484/1/SangwaniPatrickCorrectedThesis.pdf> Last accessed on $30 / 05 / 2021$

Ng'ambi, S. (2010), "Stabilization Clauses and the Zambian Windfall Tax", Zambia Social Science Journal 1, 107.

Ng'ambi, S.P. (2012), “The Effect of Stabilization Clauses in Concession Agreements”, Zambia Law Journal 43, 57.

Nicholas, B. (1992), The French Law of Contract (2 ${ }^{\text {nd }}$ edn, Oxford: Oxford University Press).

Nwaokoro, J. (2013), "Enforcing Stabilization of International Energy Contracts", Journal of World Energy Law \& Business 3, 103.

Paasirvirta, E. (1989), "Internationalization and Stabilization of Contracts versus State Sovereignty", British Yearbook of International Law 60, 315 - 323.

Paasivirta, E. (1990), Participation of States in International Contracts and Arbitral Settlement of Disputes 
(Helsinki: Lakimiesluton Kustannus).

Peel, E. (2011), Treitel: The Law of Contract (13 ${ }^{\text {th }}$ edn, London: Sweet \& Maxwell).

Peter, W. (1995), Arbitration and Renegotiation of International Investment Agreements (The Hague: Kluwer Law International).

Rosen, J.A. (1993), "Arbitration Under Private International Law: The Doctrines of Separability and Compétence de la Compétence", Fordham International Law Journal 17, 599.

Russi, L. (2008), "Chronicles of a Failure: From a Renegotiation Clause to Arbitration of Transnational Contracts", Connecticut Journal of International Law 24, 77.

Salacuse, J.W. (2000), "Rengotiating International Project Agreements", Fordham International Law Journal 24, 1319.

Salacuse, J.W. (2013), The Three Laws of International Investment: National, Contractual, and International Frameworks for Foreign Capital (Oxford: Oxford University Press).

Sands, P. \& Klein, P. (2009), Bowett's Law of International Institutions (6 ${ }^{\text {th }}$ ed, London: Sweet \& Maxwell).

Schachter, O. (1991) International Law in Theory and Practice (Dordrecht: M. Nijhoff Publishers).

Schill, S.W. (2009), The Multilateralization of International Investment Law (New York: Cambridge University Press).

Schreuer, C. (2001), The ICSID Convention: A Commentary (Cambridge: Cambridge University Press).

Schrijver, N. (1997), Sovereignty Over Natural Resources: Balancing Rights and Duties (Cambridge: Cambridge University Press).

Schwebel, S.M. (1963), "The Story of the U.N.'s Declaration on Permanent Sovereignty over Natural Resources", American Bar Association Journal 49, 463

Sereni, A.P. (1959), "International Economic Institutions and the Municipal Law of States”, Recueil des cours 96 , 129.

Sornarajah, M. (2000), The Settlement of Foreign Investment Disputes (London: Kluwer).

Sornarajah, M. (2010), The International Law on Foreign Investment ( $3^{\text {rd }}$ ed, New York: Cambridge University Press).

Stevens, P. (2008), "National Oil Companies and International Oil Companies in the Middle East: Under the Shadow of Government and the Resource Nationalism Cycle", Journal of World Energy Law \& Business 1, 5 .

Subedi, S.P. (2012), International Investment Law: Reconciling Policy and Principle (2 ${ }^{\text {nd }}$ edn, Oxford: Hart Publishing).

Suratgar, D. (1962), "Considerations affecting Choice of Law Clauses in Contracts Between Governments and Foreign Nationals", Indian Journal of International Law 2, 273.

Te'llez, F.M. (2012), "Conditions and Criteria For The Protection of Legitimate Expectations under International Investment Law", ICSID Review 27, 432.

Treitel, G.H. (1994), Frustration and Force Majeure (London: Sweet \& Maxwell).

Vivoda, V. (2009), "Resource Nationalism, Bargaining and International Oil Companies: Challenges and Change in the New Millennium", New Political Economy 14, 517.

Waelde, T.W. \& Ndi, G. (1996), "Stabilizing International Investment Commitments: International Law Versus Contract Interpretation", Texas International Law Journal 31, 215.

Warden-Fernandez, J. (2000), "The Permanent Sovereignty over Natural Resources: How it has Been Accommodated within the Evolving Economy", CEPMLP Annual Review Article, 4. Available at $<\mathrm{http}: / / w w w . d u n d e e . a c . u k /$ cepmlp/car/html/car4_art4.htm $>$ Last accessed on 31/05/2021.

Wehberg, H. (1959), "Pacta Sunt Servanda", American Journal of International Law 53, 775.

Weiss, T.G. \& Daws, S. (2007), The Oxford Handbook on the United Nations (Oxford: Oxford University Press).

Wolff, M. (1950), "Some Observations on the Autonomy of Contracting Parties in the Conflict of Laws", Transactions of the Grotius Society 35, 143.

Woodhouse, E.J. (2006), "The Obsolescing Bargain Redux? Foreign Investment in the Electric Power Sector in Developing Countries", New York University Journal of International Law and Politics 38, 121.

Yackee, J.W. (2009), "Pacta Sunt Servanda and State Promises to Foreign Investors before Bilateral Investment Treaties: Myth and Reality", Fordham International Law Journal 32, 1550. 